I NTERNATIONALMONETARY F U N D

Middle East and Central Asia Department

Financial Inclusion of

Small and Medium-Sized

Enterprises in the Middle East

and Central Asia

IMF staff team led by Nicolas Blancher

No. $19 / 02$ 
Middle East and Central Asia

\section{Financial Inclusion of Small and Medium-Sized Enterprises in the Middle East and Central Asia}

IMF staff team led by Nicolas Blancher and including Max Appendino, Aidyn Bibolov, Armand Fouejieu, Jiawei Li, Anta Ndoye, Alexandra Panagiotakopoulou, Wei Shi, and Tetyana Sydorenko 
Copyright @2019 International Monetary Fund

\section{Cataloging-in-Publication Data IMF Library}

Names: Appendino, Maximiliano, author. | Bibolov, Aidyn, author. | Fouejieu A., Armand, author. | Li, Jiawei (Research Analyst), author. | Ndoye, Anta, author. | Panagiotakopoulou, Alexandra, author. | Shi, Wei (Economist), author. | Sydorenko, Tetyana, author. | Blancher, Nicolas R., project director. | International Monetary Fund. Middle East and Central Asia Department, issuing body. | International Monetary Fund, publisher.

Title: Financial inclusion of small and medium-sized enterprises in the Middle East and Central Asia / IMF staff team led by Nicolas Blancher and including Max Appendino, Aidyn Bibolov, Armand Fouejieu, Jiawei Li, Anta Ndoye, Alexandra Panagiotakopoulou, Wei Shi, and Tetyana Sydorenko.

Description: [Washington, DC] : International Monetary Fund, [2019]. | At head of title: Middle East and Central Asia Department. | Includes bibliographical references.

Identifiers: ISBN 9781484383124 (paper)

Subjects: LCSH: Small business_Middle East. | Small business—Asia, Central. | Finance-Middle East. | Finance-Asia, Central.

Classification: LCC HD2341.A67 2019

The Departmental Paper Series presents research by IMF staff on issues of broad regional or cross-country interest. The views expressed in this paper are those of the author(s) and do not necessarily represent the views of the IMF, its Executive Board, or IMF management.

Publication orders may be placed online, by fax, or through the mail: International Monetary Fund, Publication Services P.O. Box 92780, Washington, DC 20090, U.S.A.

Tel. (202) 623-7430 Fax: (202) 623-7201

E-mail: publications@imf.org www.imfbookstore.org www.elibrary.imf.org 


\section{Contents}

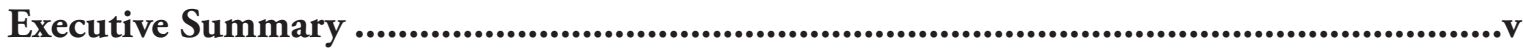

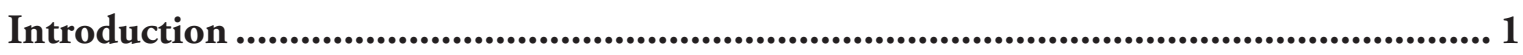

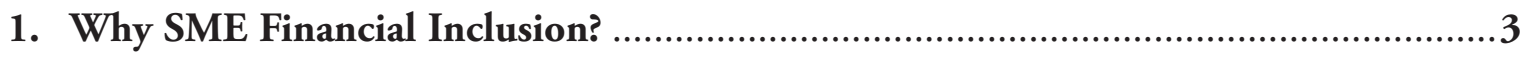

The SME Financial Inclusion Gap ..............................................................................

Benefits from Increasing SME Financial Inclusion ...........................................................

2. Scaling Up Bank Credit to SMEs.............................................................................. 11

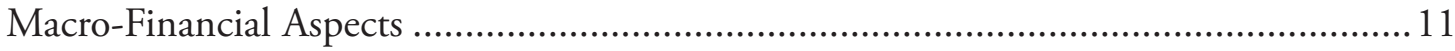

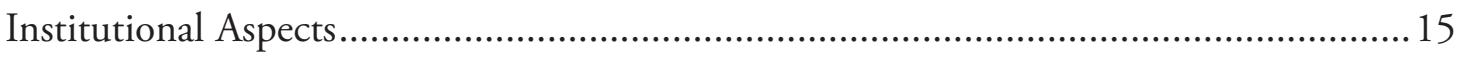

Key Priorities for MENAP and CCA Countries .......................................................... 17

3. Potential Role of Alternative Financing Channels ......................................................... 21

Capital Markets........................................................................................................ 21

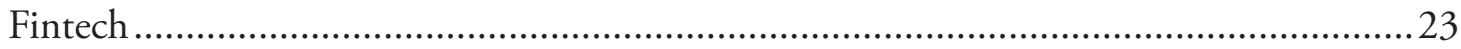

4. Policy Strategies_Unlocking SME Financial Inclusion ................................................ 33

Current Policy Initiatives.......................................................................................... 33

Need for Holistic Policy Approaches..............................................................................36

Annex 1. Methodology for the SME Financial Inclusion Index .......................................... 41

Annex 2. SME Financial Inclusion Gap.............................................................................. 43

Annex 3. Growth and Employment Benefits of Increased Access to Financing for SMEs ................................................................................................................................. 45

Annex 4. Benefits from Relaxing Constraints on SME Financial Inclusion:

Country-Specific Analysis ................................................................................................ 49

Annex 5. Access to Financing and Firm-Level Employment, Sales, and Productivity

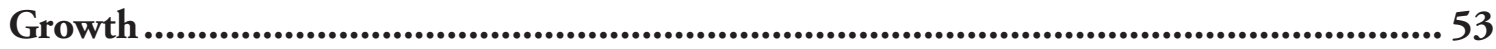

Annex 6. SME Financial Inclusion and Macroeconomic Policy .......................................... 55

Annex 7. Drivers of SME Financial Inclusion ..................................................................... 57

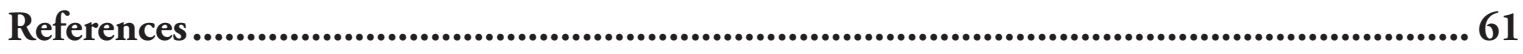




\section{Boxes}

Box 1. Literature-Benefits from Increased Financial Inclusion.....................................9

Box 2. Literature-Macroeconomic and Institutional Determinants of Financial

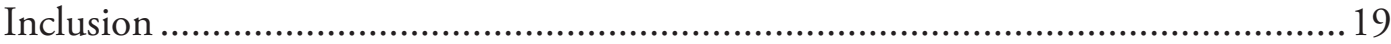

Box 3. Alibaba in China: SME Lending and Asset-Backed Securities ..........................25

Box 4. NewConnect in Poland: SME Stock Exchange ................................................26

Box 5. Dubai International Financial Centre and Fintech Development .......................31

Box 6. SME Financial Inclusion-Key Regional and International Organizations..........38

\section{Figures}

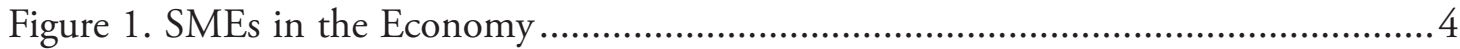

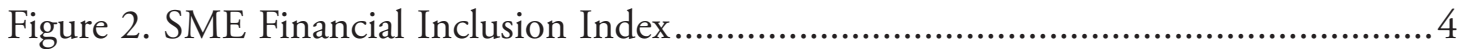

Figure 3. SME Financial Inclusion, Economic and Financial Development....................5

Figure 4. Growth and Employment Benefits of SME Financial Inclusion.......................7

Figure 5. SME Financial Inclusion and Macroeconomic Policy Effectiveness..................8 8

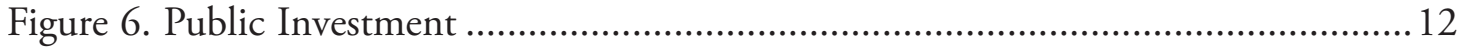

Figure 7. Credit to Private and Public Sectors.......................................................... 13

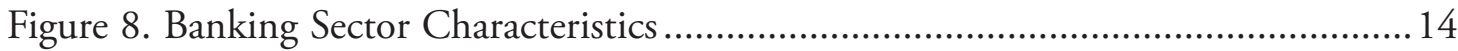

Figure 9. Employment Growth Gains from Reaching Average Credit Bureau Coverage of Emerging Market and Developing Economies ................................ 16

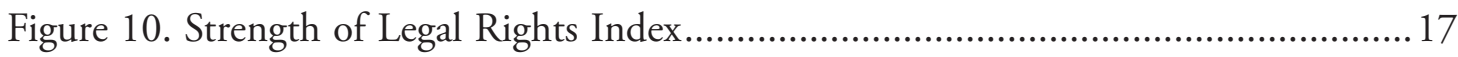

Figure 11. MENAP and CCA: Decomposition of SME Financial Inclusion Gap.......... 17

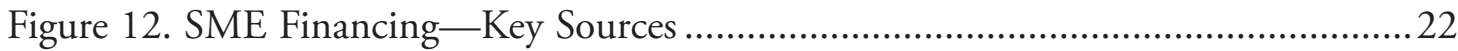

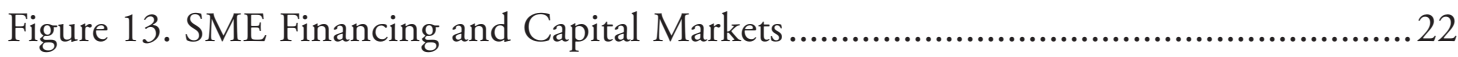

Figure 14. Capital Markets in the MENAP and CCA Regions...................................24

Figure 15. Enhancing Traditional SME Finance.......................................................2

Figure 16. Types of Fintech for SME Finance ..................................................... 28

Figure 17. Fintech Ecosystem.......................................................................... 31

Figure 18. Framework for SME Financial Inclusion ............................................. 37

\section{Tables}

Table 1. Capital Markets Ecosystem for SMEs_Policies and International Practices ....25 


\section{Executive Summary}

The importance of financial inclusion is increasingly recognized by policymakers around the world. Small and medium-sized enterprise (SME) financial inclusion, in particular, is at the core of the economic diversification and growth challenges many countries are facing. In the Middle East and Central Asia (MENAP and CCA) regions, SMEs represent an important share of firms, but the regions lag most others in terms of SME access to financing.

Improving SME financial inclusion can help increase economic growth, job creation, and the effectiveness of fiscal and monetary policy and could also contribute to financial stability. In the MENAP and CCA regions, the potential benefits are particularly high: annual economic growth could, in some cases, be boosted by up to 1 percent, potentially leading to about 16 million new jobs by 2025 in these regions.

International experience suggests that many factors can help scale up SME bank credit, including

- Economic fundamentals and financial sector characteristics, such as macroeconomic stability, limited public sector size (to avoid crowding out SME access to credit), financial sector soundness, a competitive banking system and, more broadly, a competitive and open economy that could boost SME investment and demand for credit.

- Institutional factors, such as strong governance and financial regulatory and supervisory capacity, credit information availability, and a supportive business environment, including modern collateral and insolvency frameworks, and legal systems that allow to adequately enforce property rights and contracts.

In addition, alternative channels can facilitate greater SME access to financing, including by supporting the supply of bank credit. Cross-country experi- 
ence shows that capital markets can play such a role at various stages of SME development. Similarly, fintech can both help reduce constraints on bank credit (for example, credit information or competition) and open new channels for SME financing. Both capital markets and fintech are still nascent in the MENAP and CCA regions.

A range of policies and reforms have already been implemented across countries to support SME financial inclusion. These include direct interventions to enhance bank credit, such as through state-owned SME banks, credit guarantee schemes, and interest rate regulations. In recent years, a growing number of countries have also developed national strategies to address key obstacles to household and firm financial inclusion.

A key conclusion is that partial approaches, such as policies focusing solely on direct public financing or guarantees, are unlikely to yield large benefits. Rather, meaningful, safe, and sustainable SME access to financing requires a holistic approach covering the key building blocks listed above, from macroeconomic to legal and regulatory aspects. This approach can also trigger a virtuous circle of greater SME transparency and reduced informality, bringing about broader benefits to the economy and stronger demand for credit. Finally, specific policy and regulatory frameworks are needed to encourage the development of SME financing through greater reliance on capital markets and new technologies.

The policy framework proposed in this paper can help support policymakers in formulating and implementing country-specific reform strategies for greater SME financial inclusion. The IMF and other international organizations have important roles to play in providing analytical input and concrete policy advice based on the various aspects of this framework, building on lessons from international experience. 


\section{Introduction}

Small and medium-sized enterprise (SME) financial inclusion is at the core of the economic diversification, growth, and job creation challenges in the Middle East and Central Asia (MENAP and CCA) regions. ${ }^{1}$ Financial inclusion is taking higher priority in many countries and in the international policy agenda, such as through the Financial Inclusion Action Plan endorsed at the 2010 G20 Summit in Seoul. In the MENAP and CCA regions, many countries face formidable challenges to stronger and more inclusive growth and a more vibrant private sector. ${ }^{2}$ The average share of SMEs in total bank lending in MENAP and CCA countries is only about 7 percent, the lowest in the world. The IMF and other international institutions, therefore, have a key role in supporting the prioritization of reforms and the design of policy strategies in a way that increases SME financial inclusion that is country-specific and build on international experience.

This paper highlights the macroeconomic relevance of SME financial inclusion in the MENAP and CCA regions and offers policy considerations to scale up SME financial access. Its focus is primarily on the macroeconomic and policy aspects of SME financial inclusion, and not all issues relevant

This Middle East and Central Asia (MCD) departmental paper was prepared by a team under the supervision of Aasim Husain, led by Nicolas Blancher, and including: Max Appendino, Aidyn Bibolov, Jiawei Li, Anta Ndoye, Alexandra Panagiotakopoulou, Wei Shi, and Tetyana Sydorenko (MCD); Armand Fouejieu (EUR); and Mishel Ghassibe and Samir Elsadek (summer interns). It incorporates input from staff in other IMF departments, as well as experts from the World Bank, International Finance Corporation, Asian Development Bank, and International Organization of Securities Commissions, including via an iLab brainstorming session.

${ }^{1}$ The Middle East and Central Asia region refers to 31 countries in the Middle East, North Africa, Afghanistan, and Pakistan (MENAP) and in the Caucasus and Central Asia (CCA). Financial inclusion is defined as the access to, and use of, formal financial services.

${ }^{2}$ Statement by the International Monetary Fund, Arab Fund for Economic and Social Development, and Arab Monetary Fund, Conference on Promoting Growth, Jobs, and Inclusiveness in the Arab World, January 30, 2018. 
to SME financing are covered. ${ }^{3}$ It is organized as follows: the first section presents the SME financial inclusion gap in the MENAP and CCA regions and potential macro-financial benefits from reducing this gap. The next section builds on empirical analyses to identify key drivers of SME access to financing, especially in MENAP and CCA countries. Reviews of the role of alternative channels of SME financing, such as capital markets and fintech, follow, building on international experience. The final section takes stock of existing efforts to support SME financial inclusion and suggests policy approaches that are both holistic and tailored the specific needs of MENAP and CCA countries.

\footnotetext{
${ }^{3}$ Specifically, Islamic finance, correspondent banking relationships, leasing and factoring, microfinance, and informal finance are not addressed in depth, either due to data limitations or because their macroeconomic relevance is less pronounced or they are separately subject to in-depth analytical and policy work. For instance, see Ensuring Financial Stability in Countries with Islamic Banking, IMF 2017, and Recent Trends in Correspondent Banking Relationships: Further Considerations, IMF 2017 (2017a, 2017e).
} 


\section{Chapter}

\section{Why SME Financial Inclusion?}

There is considerable scope to increase SME access to financing in the Middle East and Central Asia, and the macro-financial benefits could be substantial: annual economic growth could increase by up to 1 percent, and the effectiveness of macroeconomic policies and macro-financial stability could be enhanced.

\section{The SME Financial Inclusion Gap}

SMEs represent an important share of firms and employment in the Middle East and Central Asia. In line with world averages, SMEs represent about 96 percent of all registered companies in the region and employ about half of the total labor force (Figure 1). A relatively large share of SMEs in the region are in the informal sector.

The MENAP and CCA regions lag most other regions in terms of SME access to financing through the banking system. The average share of SMEs in total bank lending in the MENAP and CCA regions is about 7 percent, and as low as 2 percent in certain Gulf Cooperation Council countries. According to the World Bank Enterprise Survey, a comparatively high percentage of firms in the MENAP region (about 32 percent) report access to credit as a major constraint (compared with the world average of 26 percent). The percentage is lower in the CCA region (18 percent).

SMEs in the Middle East have the largest gap in financial inclusion in the world. We constructed a composite index that captures both access and usage of financial services by SMEs using principal component analysis and firm-level data from the World Bank Enterprise Survey (Figure 2, Annex 1). This financial inclusion index shows that MENAP countries lag the rest of the world in this area, while the CCA region performs slightly better but still lags Europe, Asia, and Latin America (Figure 3). 


\section{Figure 1. Small and Medium-sized Enterprise in the Economy}

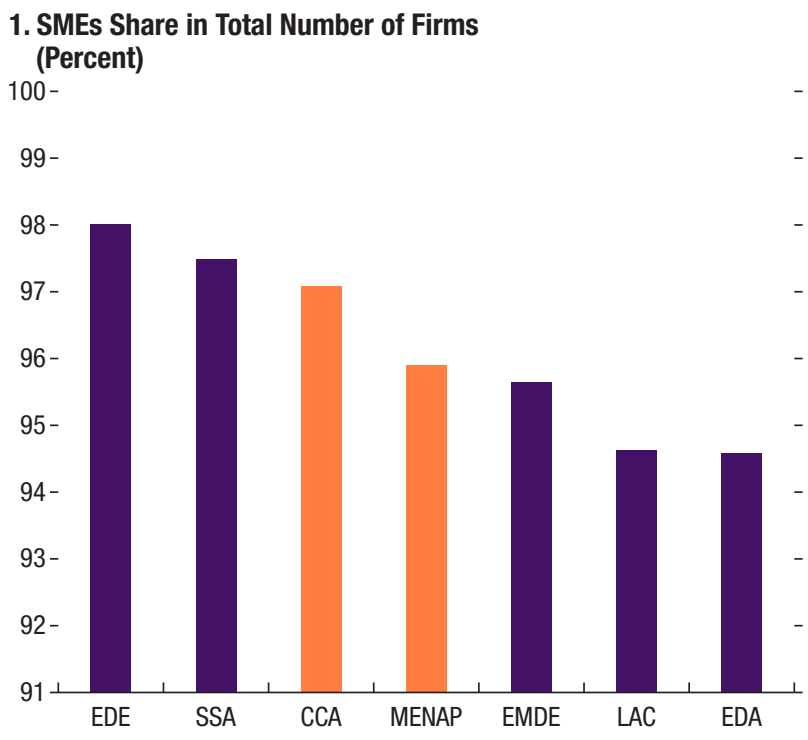

\section{SME Share in Total Employment (Percent)}

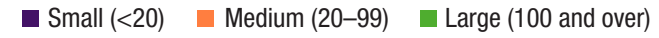

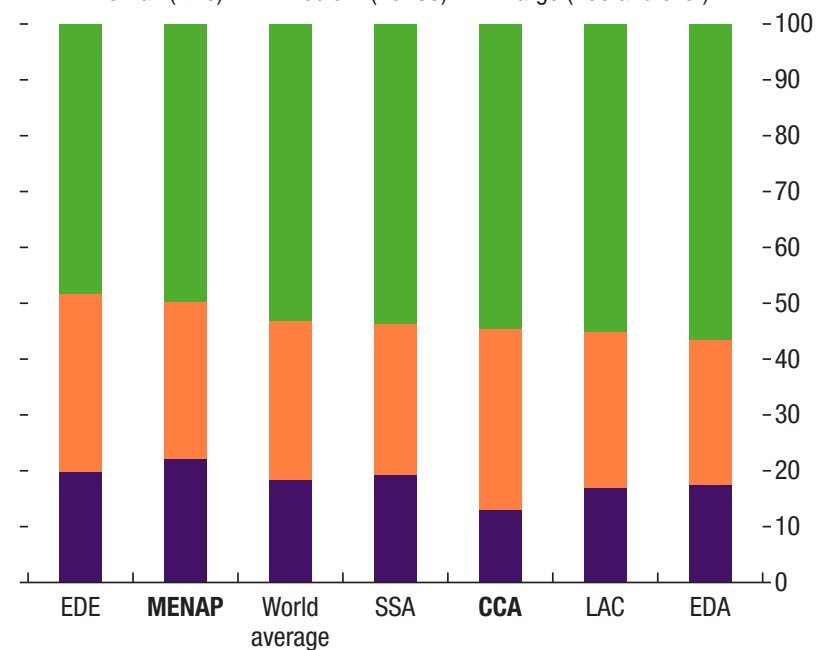

Source: World Bank Enterprise Surveys, latest available data.

Note: EDE = Emerging and Developing Europe; SSA = Sub-Saharan Africa; CCA = Caucasus and Central Asia; MENAP = Middle East, North Africa, Afghanistan, and Pakistan; EMDE = Emerging Markets and Developing Economies; LAC = Latin America and the Carribean; EDA = Emerging and Developing Asia; SME = small and medium-sized enterprise.

Figure 2. SME Financial Inclusion Index

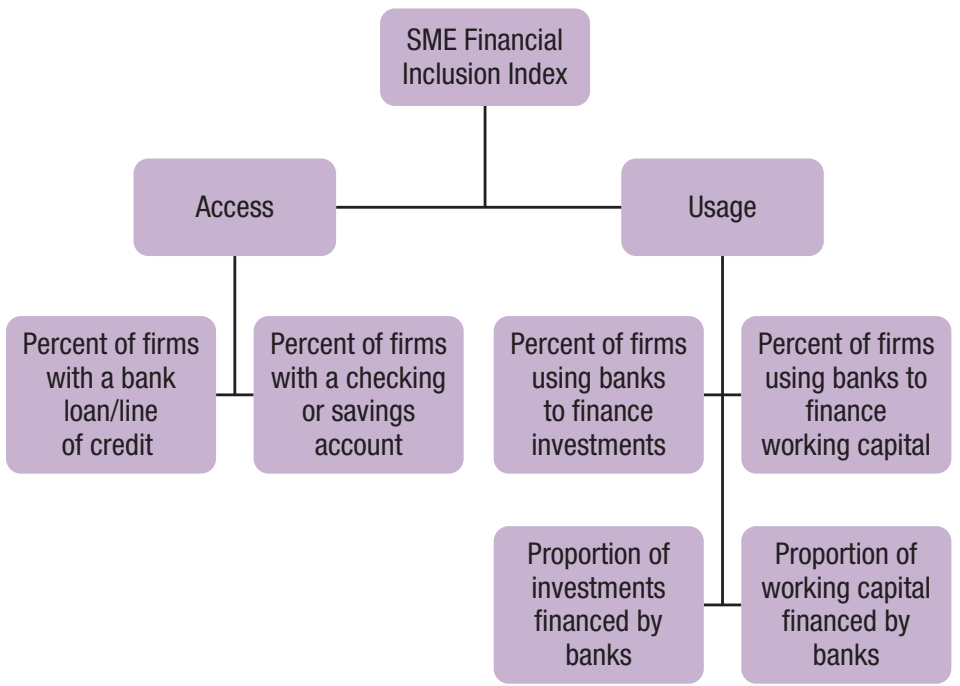

SME access to financing in the Middle East and Central Asia is also low compared with other countries at similar levels of economic development. Significant deviations of observed financial inclusion indices from values predicted based on economic fundamentals indicate that the region could achieve higher levels of financial inclusion even within the prevailing macroeconomic environment. In addition, the concentration of credit has been rising, with the share of SMEs decreasing, both globally and in the Middle East and Central Asia.

Source: Author's illustration. 
Figure 3. SME Financial Inclusion, Economic and Financial Development

1. SME Financial Inclusion Index for Emerging Markets

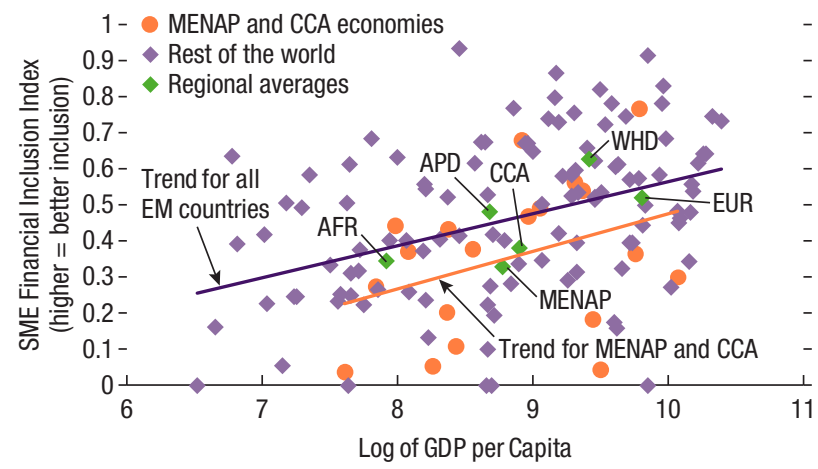

3. SME Lending by region (Percent of Total Lending)

$$
18-
$$

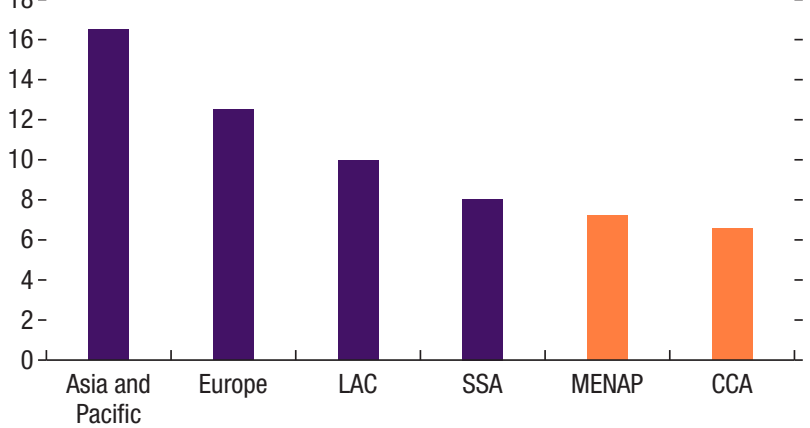

2. Gap Compared to 90th Percentile (SME)

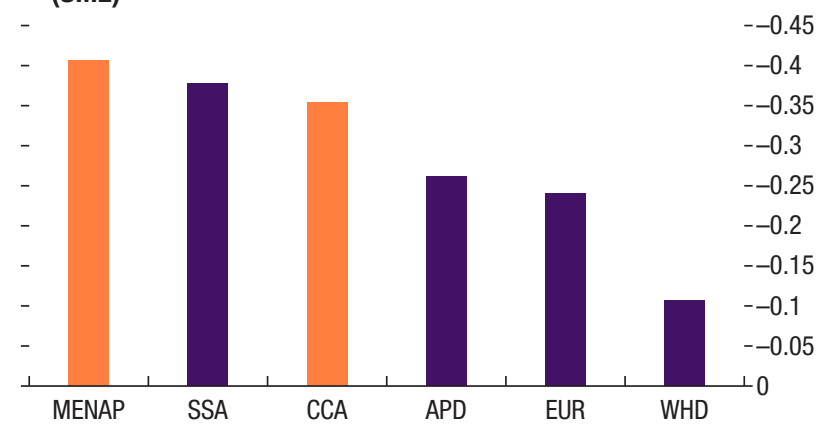

\section{Middle East and Central Asia: Credit to SMEs} (Percent of Total Lending)

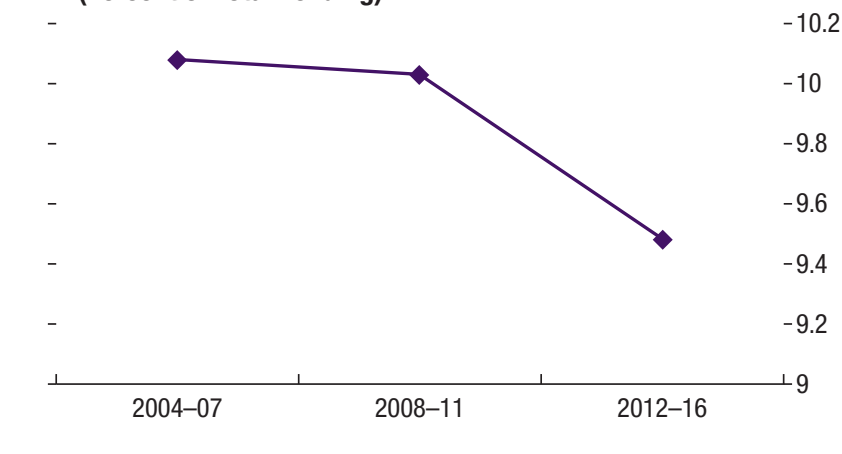

Sources: Financial Access Survey, World Development Indicators, World Bank Enterprise Surveys, and IMF staff calculations.

Note: The financial inclusion gap is the difference in the SME financial inclusion index (Annex 1) between respective region's average and the 90th percentile of the sample. MENAP = Middle East, North Africa, Afghanistan, and Pakistan; CCA = Caucasus and Central Asia; SSA = Sub-Saharan Africa; APD = Asia Pacific; EUR = Europe; WHD = Western Hemisphere; $L A C=$ Latin America and Caribbean; SME = small and medium-sized enterprise .

${ }^{1}$ Financial Institution Depth index is a composite index, which measures the depth of the banking system, pension and mutual funds as well as the insurance sector.

\section{Benefits from Increasing SME Financial Inclusion}

This section illustrates the nature and magnitude of potential macro-financial benefits from greater SME financial inclusion. Complementing and extending findings from the literature, it presents results from different methodological approaches (cross-country and country-specific, firm-level, and macro data-based empirical analyses) that were used to gauge the impact of greater SME financial inclusion on economic growth, job creation, the effectiveness of macroeconomic policy, and macro-financial stability. 


\section{Economic Growth}

Closing the SME financial inclusion gap with respect to emerging market and developing economies would help increase annual economic growth in some MENAP and CCA countries by up to 1 percent. Analyses presented in Annexes 3-5 complement the existing literature on financial inclusion (Box 1) by providing evidence of gains specifically from SME financial inclusion. Static and dynamic regression frameworks based on cross-country macro-level data suggest that closing the SME financial inclusion gap vis-à-vis emerging market and developing economies could increase growth by an average of 0.3 percentage point annually (Figure 4). Estimates of gains in employment and labor productivity growth based on firm-level data and combined with growth accounting calculations indicate potentially higher GDP growth gains (about 1 percentage point). Finally, country-specific approaches using dynamic stochastic general equilibrium (DSGE) model calibrations suggest that relaxing key constraints to SME access to financing could yield long-term cumulative growth benefits of about 5 percent in certain MENAP and CCA countries. ${ }^{1}$

\section{Job Creation}

SMEs have a key role in driving employment, especially in developing economies. SMEs are the largest contributor to employment across all country income groups. They are also large contributors to employment growth (Kumar 2017). Ayyagari, Demirguc-Kunt, and Maksimovic (2014) find that SMEs (fewer than 100 employees) account for nearly half of the workforce in the average country and that small firms (fewer than 20 employees) are the highest contributors to employment growth. They also find that the youngest firms have the highest employment growth.

In the MENAP and CCA regions, greater SME financial inclusion could help raise the employment rate, potentially creating about 16 million jobs by $2025 .^{2}$ Firm-level analyses suggest that giving firms access to formal financing leads to an increase of 1 percentage point in their annual employment growth and of 2.4 percentage points in their labor productivity growth, in line with findings from the literature. These estimated gains are much larger for SMEs (1.3 percentage points and 2.3 percentage points, respectively) than for large firms (0.8 percentage point and 1.8 percentage points).

\footnotetext{
${ }^{1}$ These constraints, which may force SMEs to operate at a suboptimal scale due to limited access to credit, include asymmetric information, the higher costs of serving SMEs, limited financial literacy, and insufficient collateral requirement and recovery frameworks.

${ }^{2}$ In the MCD region, Arab countries have the highest level of youth unemployment in the world (25 percent on average), and more than 27 million young people will enter those countries' labor market in the next five years. See Baduel and others (2018).
} 
Figure 4. Growth and Employment Benefits of SME Financial Inclusion

Macro-level analysis

1. Growth Benefits of Closing the SME FI Gaps with Respect to Global Average

(Increase in real GDP, percentage points) 3.5

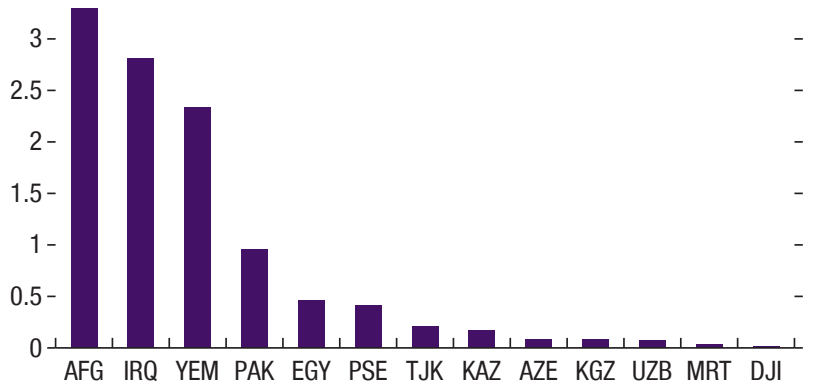

Firm-level analysis

3. Employment Growth Gains from Access to Formal Finance ${ }^{1}$ (Percentage points)

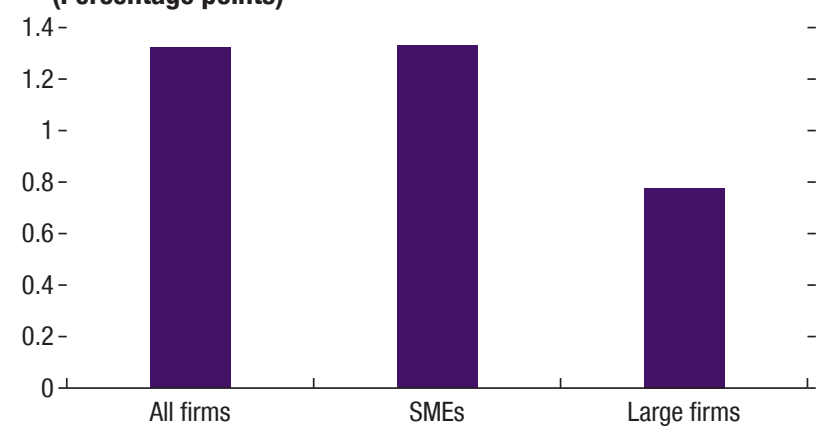

2. Employment Benefits, 2010-251 (Million employed people)

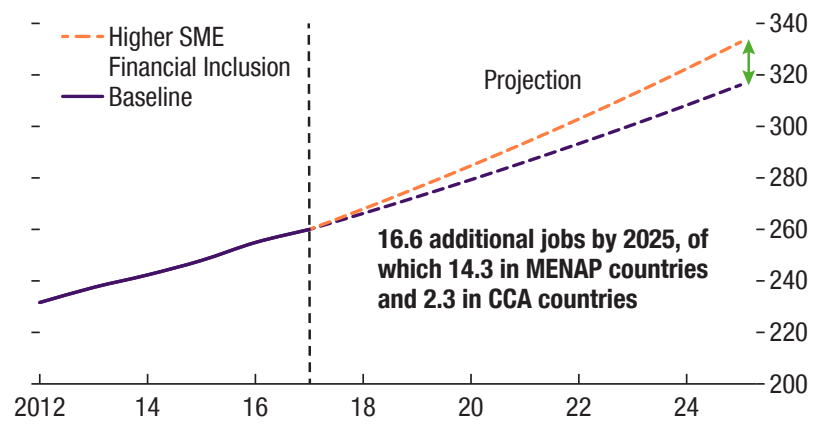

4. Labor Productivity Growth Gains from Access to Formal Finance ${ }^{1}$ (Percentage points)

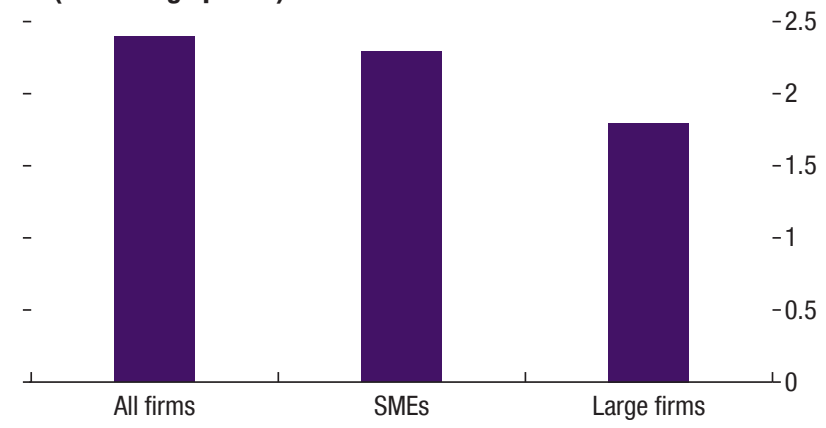

Sources: World Bank Enterprise Surveys, International Labour Organization, and IMF staff calculations.

Note: Panel 1 uses, ISO country codes. SME FI = small and medium-sized enterprise financial inclusion; MENAP = Middle East, North Africa, Afghanistan; and Pakistan; CCA = Caucasus and Central Asia.

${ }^{1}$ Annex 5 provides details on the estimates.

Within SMEs, employment gains are largest for small firms (1.7 percentage points), which are the most credit constrained, while productivity gains are largest for medium firms (2.5 percentage points), possibly because they gain relatively more by enhancing the capital intensity of their production. Macro-level analyses suggest that a 1 percent rise in SME credit leads to a decrease in unemployment of about 0.1 percent for a sample of emerging market and developing economies, and of up to 0.2 percent for MENAP and CCA countries.

\section{Macroeconomic Policy Effectiveness}

Greater SME financial inclusion is associated with more effective fiscal policy, including through better tax collection. A vector autoregression approach 
Figure 5. SME Financial Inclusion and Macroeconomic Policy Effectiveness ${ }^{1}$
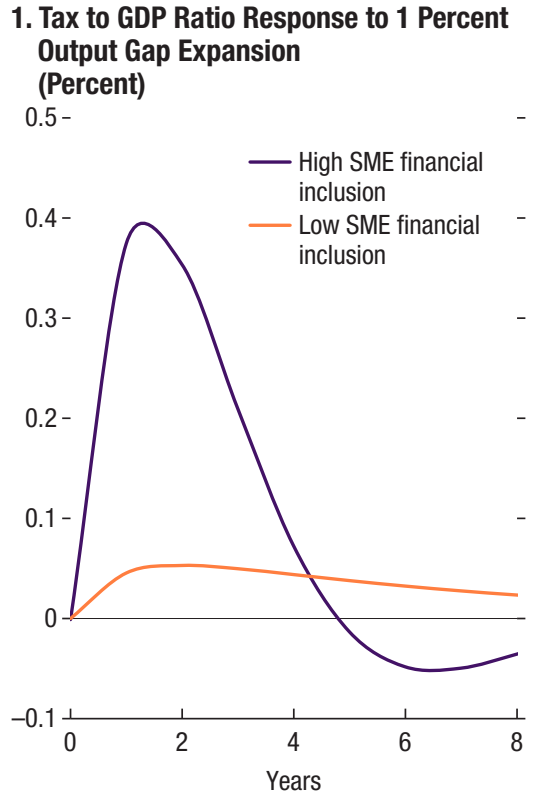

2. Output Gap Response to 100bp Monetary Tightening (Percent)

\section{SME Financial Inclusion and Inflation Aversion \\ (Ratio of variances of output gap and inflation)}

$-\quad-0.8$

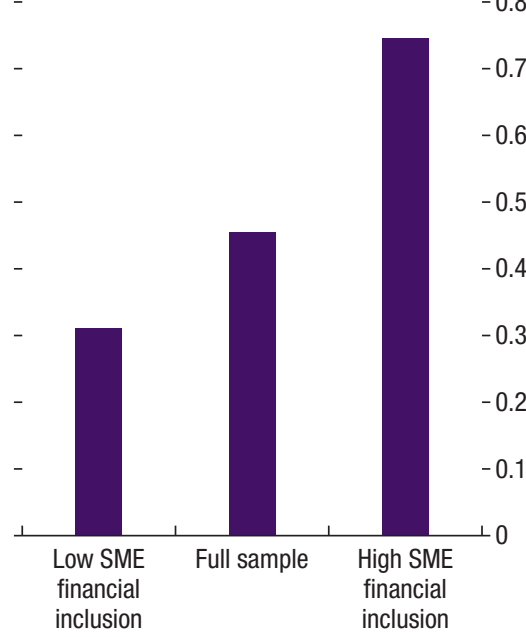

Sources: World Bank Enterprise Surveys, Haver Analytics, IMF staff calculations. Note: $\mathrm{SME}=$ small and medium-sized enterprise; $\mathrm{bp}=$ basis points .

${ }^{1}$ Annex 6 provides details on the estimates.

indicates that following a positive output gap shock, MENAP and CCA countries whose SME financial inclusion index is high raise tax revenues more effectively (Figure 5, Annex 6). IMF (2018b) also shows that greater financial inclusion is associated with higher revenue and expenditure as a share of GDP.

Monetary policy transmission and price stability also appear to be enhanced in countries with higher SME financial inclusion. As more SMEs have access to formal lending, the role of the interest rate in the economy may increase, improving monetary transmission and allowing monetary authorities to better ensure price stability. The impulse response of the output gap to a nominal interest rate shock indeed tends to be stronger in countries with high SME financial inclusion. Similarly, central banks' aversion to inflation (measured by the ratio of variance of the output gap and inflation) increases with SME financial inclusion.

\section{Financial Stability}

Greater financial inclusion can support financial stability provided strong risk management and financial supervision are in place. Greater extension of 


\section{Box 1. Literature-Benefits from Increased Financial Inclusion}

Closing the SME financial inclusion gap can bring about significant gains in growth potential. Bhattacharya \& Wolde (2010) establish a negative relationship between the percent of firms reporting access to financing as a major constraint and per capita income growth rates. Their point estimate suggests that closing the gap between the average level of access to financing in the MENAP region and the world average is associated with an additional 0.1 percent in the rate of annual growth (all else equal). The marginal growth benefits from financial inclusion decline as financial development and inclusion increase (Sahay and others 2015, consistent with Arcand, Berkes, and Panizza 2015 and de la Torre, Ize, and Schmukler 2011). Very low financial inclusion in the MENAP and CCA regions suggests significant untapped potential for growth through increased access to financing for SMEs.

Productivity and employment gains from increased access to financing are higher for SMEs than for large firms. Beck and others (2008) suggest that better financial intermediation exerts a disproportionately positive impact on growth in industries with a larger share of small firms. Ayyagari and others (2016) show that the impact on employment is stronger among micro, small and medium enterprises than among larger firms. Taking the introduction of credit bureaus in a sample of 70 developing economies as a positive credit shock, they find that improved access to financing increased employment growth by about 3.5 percentage points among micro, small and medium enterprises, compared with only 1.2 percent for larger firms. Chodorow-Reich (2014) and Popov and Rocholl (2016) show that increased financing constraints during recessions put more downward pressure on employment by SMEs than by large firms. Finally, Berton and others (2018) find that the employment effect of credit restrictions is concentrated on small firms.

Household financial inclusion supports more effective macroeconomic policy frameworks. IMF (2018b) finds that (1) household financial inclusion is associated with higher revenue and expenditure as a share of GDP, and that it can also amplify the size of the fiscal multiplier, and (2) the output elasticity to interest rates is higher for countries with greater household financial inclusion. Similarly, Mehrotra and Yetman (2014) predict that the ratio of output volatility to inflation volatility increases household financial inclusion when monetary policy is optimal. Their results confirm the hypothesis of better monetary transmission and price stability for economies with a higher share of financially included consumers. 
credit to SMEs can contribute to financial stability because it allows banks to better diversify their credit portfolios and risk exposure. However, SME credit is a relatively risky asset class, and if it grows rapidly may lead to a buildup of unsound credit exposure. Managing this policy trade-off requires proper institutional safeguards, including sound financial supervisory frameworks, to ensure strong credit discipline and risk management standards. ${ }^{3}$

${ }^{3}$ Sahay and others (2015). 


\section{Chapter}

\section{Scaling Up Bank Credit to SMEs}

The analysis of SME credit drivers in emerging market and developing economies helps identify the key constraints to SME financial inclusion in MENAP and CCA countries. ${ }^{1}$ In addition to the overall level of economic development, these include governance, credit information availability, the level of competition, and the quality of the business environment.

\section{Macro-Financial Aspects}

This section illustrates that economic fundamentals and financial sector characteristics are key determinants of SME financial inclusion. A broad range of macro-financial variables are examined and, as presented below, several are found to play a significant role in facilitating or constraining SME access to credit (Annex 7).

\section{Public Sector Role in the Economy}

The size and efficiency of the public sector has an important influence on SME access to credit (Figures 6 and 7):

\footnotetext{
${ }^{1}$ See Annex 6. The empirical analysis covers a large sample of countries, including from the MENAP and CCA regions. Data limitations allow to identify correlations but not causal effects. While the focus of this paper is primarily on supply-side determinants of bank credit, low SME credit may reflect broader characteristics of the economy that depress SME demand for credit, such as informality, low financial literacy, and market regulations or concentration issues that affect SME investment. For more on the role of these demand-side factors in the Middle East and Central Asia, see IMF (2018c).
} 
Figure 6. Public Investment ${ }^{1}$

(Percent of total investment, average, 1995-latest available)

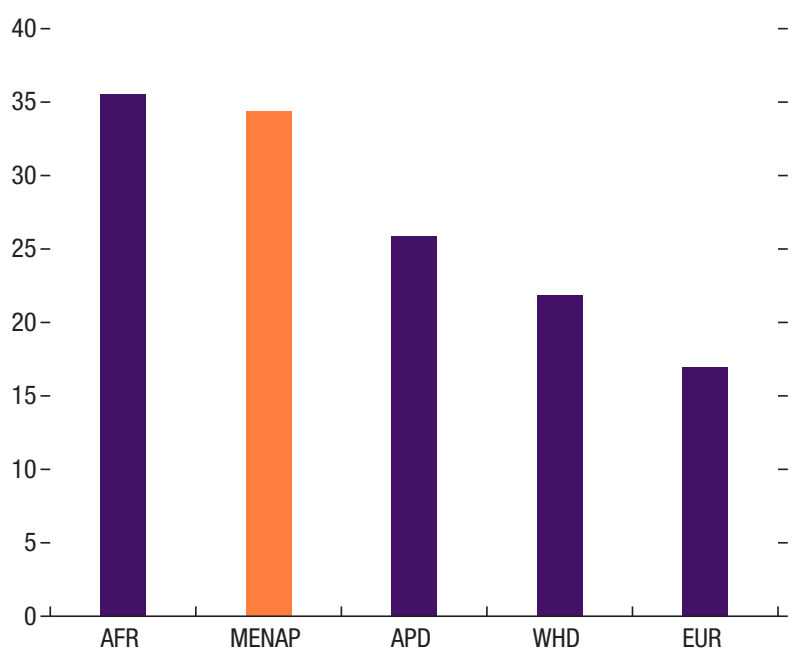

Source: World Economic Outlook.

Note: AFR = Africa; MENAP = Middle East and North Africa; Afghanistan and Pakistan; APD = Asia Pacific; WHD = Western Hemisphere; EUR = Europe

${ }^{1}$ CCA countries are omitted due to the lack of data.
- A higher share of public investment in total investment is negatively correlated with SME financial inclusion. ${ }^{2}$ Specifically, in the MENAP region, a one percent increase in public investment may lead to a 0.7 percent decline in SME financial inclusion (against an EMDE average of 0.2 percent). Public investment represents on average 34 percent of total investment in MENAP countries (against 24 percent in other EMDEs).

- In addition, greater government effectiveness is associated with improved SME access to finance. This association is stronger in MENAP countries (and to a lesser extent in CCA countries) than in other regions.

- $\quad$ Large government and SOE financing needs can also crowd out credit to the private sector, including SMEs, especially where SOEs benefit from preferential tax or regulatory treatment and easier access to bank credit. More broadly, a large role of the state in the economy often creates an uneven playing field for SMEs, exposing them to tougher competition or making it harder for them to attract workers. In the MENAP region, credit to government and SOEs (as a percent of GDP) is higher than in other regions, while it is lower in the CCA region. Available data also show that while EMDEs with deeper credit markets (total credit relative to GDP) tend to have proportionally slightly more credit going to the public sector than the private sector, the effect is much more pronounced in the MENAP region. This suggests that crowding out of the private sector by the state may be more of an issue in MENAP than elsewhere, especially in MENAP economies with deeper credit markets.

\section{Macroeconomic Stability}

Price stability has a positive impact on SME access to financing. Low inflation is a key signal of macroeconomic stability, associated with lower risk perception, stronger private sector confidence and demand for credit, and thus increased credit supply to SMEs. Our analysis confirms the negative relationship between inflation and SME financial inclusion.

\footnotetext{
${ }^{2}$ The share of government investment is used as a proxy for the size of the public sector in the economy. Fiscal balance, another proxy for private sector crowding out, is not significantly correlated with SME financial inclusion.
} 
Figure 7. Credit to Private and Public Sectors

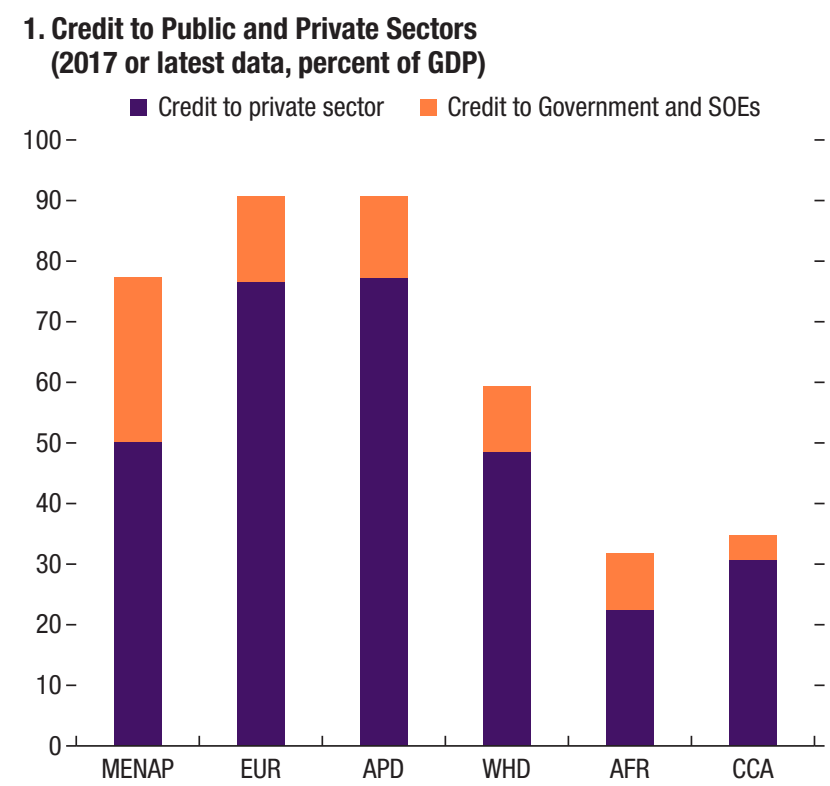

(2017 or latest data, percent of GDP)

100

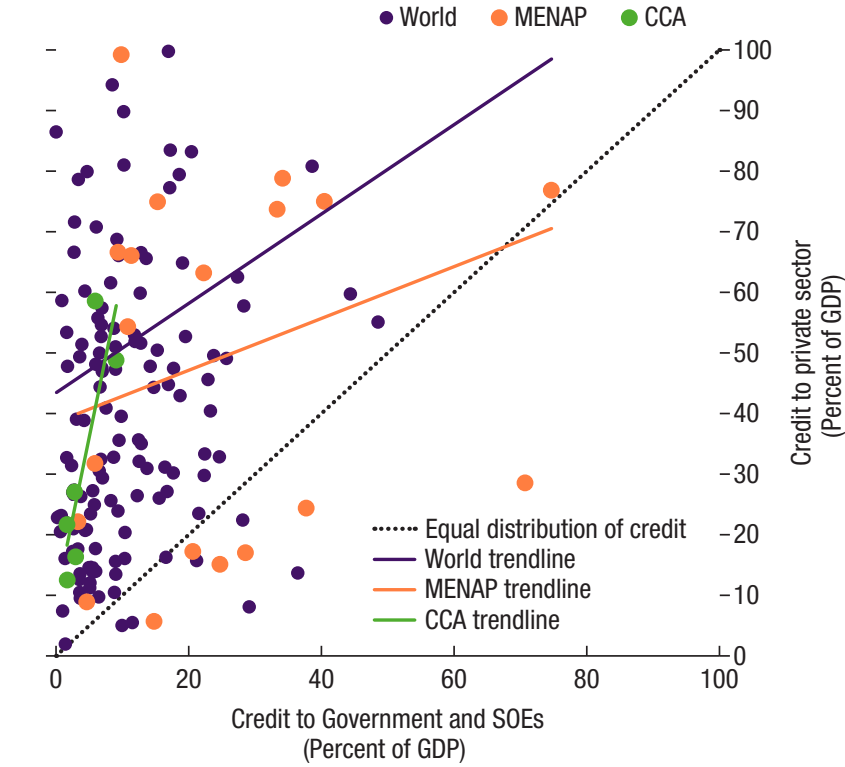

Sources: International Monetary Fund, International Financial Statistics, World Bank and OECD GDP estimates; and IMF staff estimates. Note: MENAP = Middle East and North Africa, Afghanistan and Pakistan; CCA = Caucasus and Central Asia; EUR = Europe, APD = Asia Pacific; WHD = Western Hemisphere; AFR = Africa.

\section{Financial Sector Characteristics}

Financial sector soundness is positively associated with SME financial inclusion. Financial sector stability can improve financial inclusion by enhancing trust in the financial system and by increasing the likelihood of formal saving. ${ }^{3}$ We find that bank resilience, as measured for instance through bank $Z$-scores and reliance on core funding (bank deposits), supports SME access to financing, whereas weak asset quality undermines it. The importance of these factors for SME financial inclusion appears stronger in the MENAP region than in other emerging market and developing economies. In the CCA region, low asset quality in Azerbaijan and Kazakhstan (nonperforming loan ratios of about 20 percent), for instance, seems to limit the financial sector's contribution to economic growth.

A lack of competition among banks reduces access to financing for SMEs. In line with findings from the literature, bank competition is found to have a positive impact on SME access to financing. ${ }^{4}$ Relative to other regions, MENAP — and in particular Gulf Cooperation Council countries_countries

${ }^{3}$ Cihak and others (2016).

${ }^{4}$ Love and Martinez Peria (2015). 
Figure 8. Banking Sector Characteristics
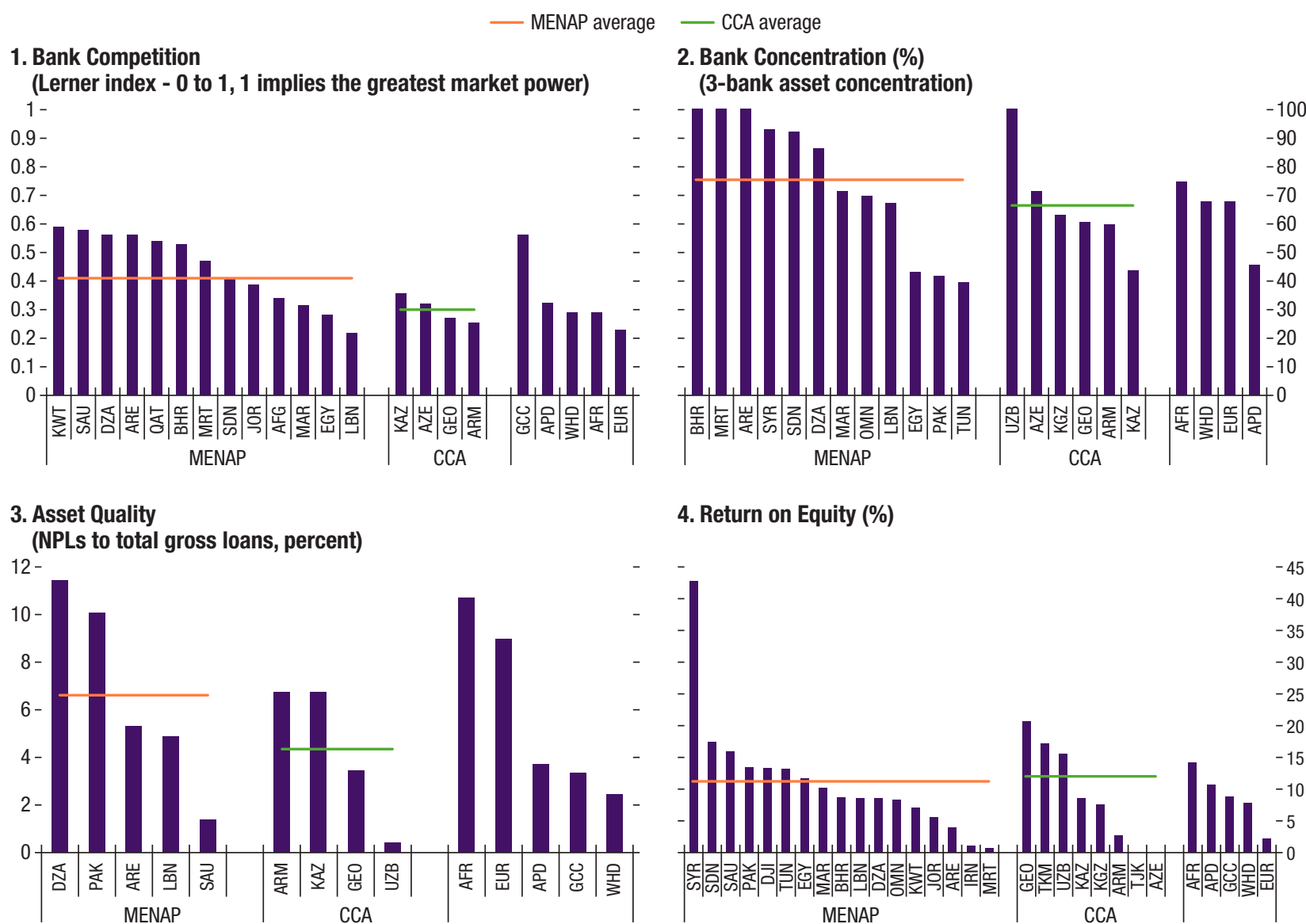

\section{Return on Equity (\%)}

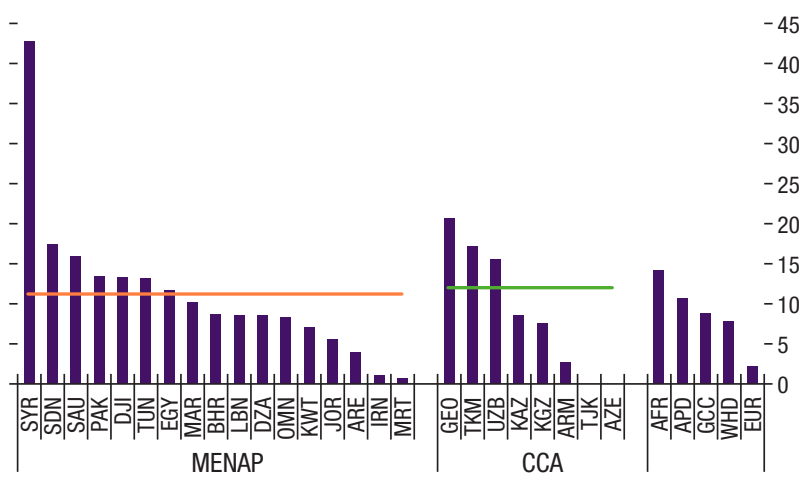

Sources: World Bank Finstats Database, 2016 or latest available, World Bank Global Financial Development dataset, authority data, and IMF staff calculations.

are behind in terms of bank competition (Figure 8). Facilitating market entry could thus improve access to credit for SMEs. Relatedly, banking sector concentration, which is high in the MENAP region, is often associated with higher interest rate margins and bank profitability and may discourage lending to smaller firms.

\section{Economic Competition}

Increased market competition and diversification could play a key role in promoting SME productivity and financial inclusion in MENAP and CCA countries. Among key features of an economy that promote a favorable environment for SME investment and financial inclusion are adequate infrastructure, economic diversification, and competition within and across sectors. Conversely, economies with large informal sectors tend to face tighter 
constraints on SME access to formal financial services. Our analysis suggests that compared to other regions, competition is a particularly important factor in MENAP and CCA countries, where significant economic activity is often concentrated in the public sector or a limited number of large firms, which is likely to lead to barriers to entry and lower SME productivity. Diversification also has a substantial impact in CCA countries.

\section{Institutional Aspects}

Although the macro-financial factors listed earlier are prerequisites, institutional factors are also essential for SME financial inclusion. Examination of a broad range of related variables shows that several play a significant role in facilitating or constraining SME access to credit and productive potential, especially in the MENAP and CCA regions.

\section{Governance}

Strong governance and stable institutions generally support SME access to formal financial services. Non-transparent systems tend to benefit large firms that are better connected than SMEs. Faccio (2006) finds that large firms tend to be more politically connected in countries with poor institutional quality (that is, with weak voice and accountability rules and significant corruption) and as a result benefit from greater access to bank financing. In addition to crowding out smaller firms, this may also pose risks to financial stability due to lower risk management standards. ${ }^{5}$ Our empirical analysis shows that control of corruption, voice, and accountability (capturing citizens' perception of participation in selecting their government, freedom of expression and association, and free media) — as well as political stability_-are positively correlated with SME financial inclusion. The importance of corruption and political risks is particularly strong for MENAP countries.

\section{Financial Regulation and Supervision}

Sound financial regulatory and supervisory frameworks help enhance SME financial inclusion. As noted, such frameworks are critical in order to monitor and address potential emerging risks and to support financial deepening and inclusion programs. Our analysis confirms that financial supervisory capacity effectively contributes to SME financial inclusion, especially in

\footnotetext{
${ }^{5}$ This is also consistent with the Basel Core Principles for Effective Banking Supervision, especially Principle 20 , which focuses on abuses and potential conflicts of interest arising from transactions between related parties that may be prone to lack of due diligence or market-related terms.
} 
Figure 9. Employment Growth Gains from Reaching Average Credit Bureau Coverage of Emerging Market and Developing Economies ${ }^{1}$

(Percentage points)

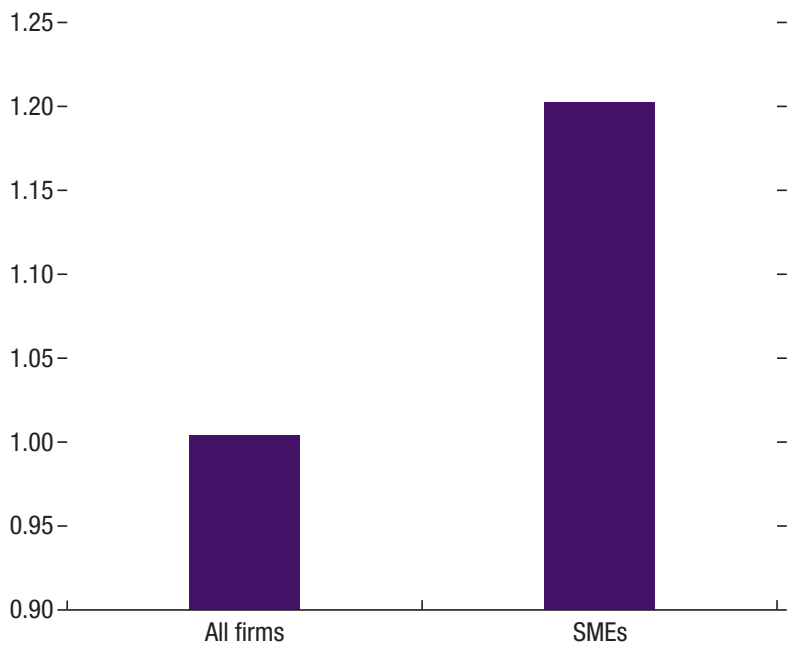

Sources: World Bank Enterprise Surveys and Doing Business Indicators; IMF staff estimates.

${ }^{1}$ Annex 5 provides details on the estimates. the MENAP region. In addition, financial inclusion and anti-money laundering and combating the financing of terrorism (AML/CFT) can be mutually supportive, including because the use of formal financial services improves the traceability of financial transactions. ${ }^{6}$

\section{Credit Information}

Credit information is a key factor for SME access to formal financing, including through reduced collateral requirements and borrowing costs. Improved quality and availability of credit information can lead to large benefits in terms of financial inclusion, as well as employment and growth, particularly for SMEs. Specifically, if credit bureau coverage increased to the EMDE average in MENAP and CCA countries, it would raise employment by 1 percentage point for all firms and by 1.2 percentage points for SMEs (Figure 9). Country-specific analysis also suggests that these gains can be even larger in jurisdictions where credit registry coverage is lower. In countries where collateral requirements are very high (such as Armenia, Azerbaijan, and Tunisia, whose average collateral requirements can be as high as 250 percent of loan value), better credit information could help relax such constraints and unlock SME access to financing. In the Kyrgyz Republic, obstacles to credit monitoring are very large and associated with particularly elevated interest rate margins (close to 20 percent).

\section{Business Environment}

Legal and institutional frameworks related to property rights, contract enforcement, and insolvency regimes are key requirements for SME financial inclusion. Constraints on contract enforcement and property rights and registration, as well as high business start-up costs and ineffective insolvency regimes, are negatively correlated with SME financial inclusion. Indeed, modern cadasters and strong property rights allow for greater alienability of assets, which can be transferred, sold and collateralized more easily, facilitating access to finance. Together with higher tax rates for SMEs, shortcomings in

\footnotetext{
${ }^{6}$ Lyman and Noor (2014).
} 
Figure 10. Strength of Legal Rights Index $(0-12 ; 12$ is the best performance)

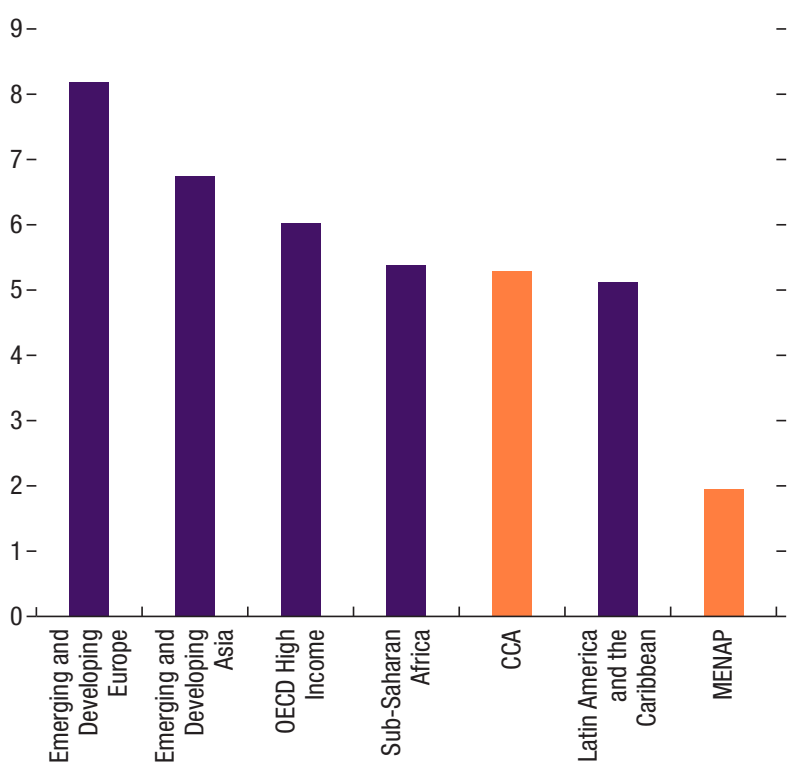

Figure 11. MENAP and CCA: Key Priorities to Boost SME Financial Inclusion ${ }^{1,2,3}$

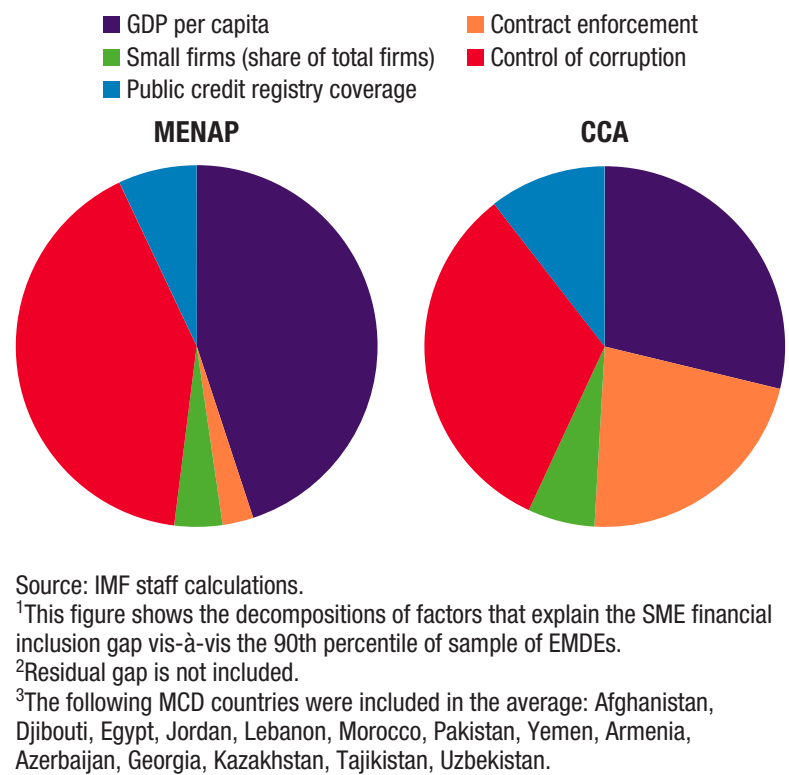

Source: World Bank Doing Business Report 2018

these areas motivate SMEs to remain in the informal sector, thereby limiting their access to credit. The MENAP and CCA regions lag in many of these areas (Figure 10).

\section{Key Priorities for MENAP and CCA Countries}

The analyses performed help prioritize reforms to enhance SME financial inclusion in MENAP and CCA countries (Figure 11). These analyses examined the relationships between a large set of macroeconomic, financial, and institutional factors and SME financial inclusion. They are consistent with findings from the broader literature (Box 2) and help identify the main areas for economic reform that would reduce the SME financial inclusion gap between MENAP and CCA countries and the best-performing countries:

- Economic development (income per capita), which captures country characteristics such as quality of infrastructure, education, and health, and explains the largest share of the financial inclusion gap in MENAP and CCA countries.

- Governance (control of corruption), which is the second most important determinant of SMEs' limited access to formal financing in the two sub-regions. 
- Credit information availability (coverage of credit registries), which also plays a key role.

- Economic competition (proxied by the share of small firms in the private sector), which suggests that market distortions hamper SME growth, demand for credit, and access to financing.

- Business environment, including legal and institutional frameworks that facilitate enforcement of property rights and contracts, as, which reduces SME activity and access to financing because of the higher cost of doing business.

Insolvency regimes, credit information, and collateral frameworks also play a key role. Cross-country studies such as Djankov, McLiesh, and Shleifer (2007) show that creditor protection and credit registries are important determinants of private credit. Based on an index of credit bureau data quality in eastern European and former Soviet Union countries (including Caucasus and central Asian countries), Brown, Jappelli, and Pagano (2009) find that improvements in the index raise credit availability and reduce its cost. While cross-country evidence suggests that information sharing is associated with higher credit, some studies based on loan-level data also show that mandatory information sharing reduces credit at the extensive and intensive margins (for example, Bos, De Haas, and Millone 2016). Love, Martinez Peria, and Singh (2016) find that the introduction of collateral registries for movable assets can increase the likelihood of firm access to bank financing by 10 percentage points, while reducing lending rates and increasing loan maturities. Dabla-Norris and others (2015b) show that relaxing collateral constraints has beneficial impacts on GDP across all countries. Insolvency regimes are often too costly, time-consuming, and inefficient in middle-income countries, especially in countries with legal systems of French origin. This is confirmed for MENAP and CCA countries in a survey-based analysis of insolvency regimes in 88 countries (14 of which are MENAP and CCA countries) by Djankov and others (2008). 


\section{Box 2. Literature-Macroeconomic and Institutional Determinants of Financial Inclusion}

Economic fundamentals are major determinants of financial inclusion. Higher incomes and better physical infrastructure increase savings and the pool of available funds, as well as access to financing (Dabla-Norris and others 2015a). Allen and others (2012) show that education is also a significant determinant of household ownership and use of accounts in the formal financial system. Better governance can help enforce financial contracts for SMEs, which facilitates their access to financing (Rojas-Suárez and Amado 2014). Macro-financial instability can dramatically affect credit and other financial services to SMEs - for example, as banks restore their capital ratios by curtailing credit, especially to riskier borrowers (Rojas-Suárez 2016).

Strong banking competition and low information asymmetries facilitate SME financial inclusion. Love and Martinez Peria (2015) find a positive impact of increased banking competition on firms' access to credit, and that the impact depends on the coverage of credit bureaus. Anzoategui, Martinez Peria, and Rocha (2010) find that banking sectors in the MENAP region are less competitive than in most other developing economies. Empirical evidence regarding the impact of foreign bank entry remains mixed. Finally, weak competition, high concentration, and the prevalence of public ownership in the banking sector are specifically highlighted by the World Bank (2016) as key constraints on SME financing in Gulf Cooperation Council countries. 



\section{Chapter}

\section{Potential Role of Alternative Financing Channels}

Alternative channels, especially capital markets and fintech, could facilitate greater SME financial inclusion, either by supporting the supply of bank credit or by opening new financing channels. Cross-country experience shows that a range of policy and institutional conditions are required to develop these channels in the MENAP and CCA regions.

\section{Capital Markets}

International experience shows that capital markets can play a significant role in serving the specific financing needs of SMEs. Such a role can be direct but also (and possibly more important) indirect by helping channel funding to intermediaries that have solved the microeconomic challenges of lending to small businesses. Such intermediaries include banks, which raise funds in capital markets and may intervene at various stages of the SME life cycle (Figure 12). ${ }^{1}$ In the initial stages, when firms generate little revenue and present high information asymmetry, access to most sources of formal financing is limited and entrepreneurs rely on their own savings or seed capital. Start-up companies with growth potential but elevated risks may attract venture capital and specialized (for example, private equity) funds. As SMEs grow and build a performance track record, sources of credit such as bank loans or asset-based lending may become increasingly available, and loan securitization may also help mobilize new financing. Finally, developed SMEs may issue debt and equity through over-the-counter or exchange markets.

Weak savings mobilization through the formal financial system is an impediment to SME capital market development in the MENAP and CCA regions (Figure 13). Household saving rates in the formal financial system are low by

\footnotetext{
${ }^{1}$ IOSCO (2015) and OECD (2015).
} 
Figure 12. SME Financing-Key Sources

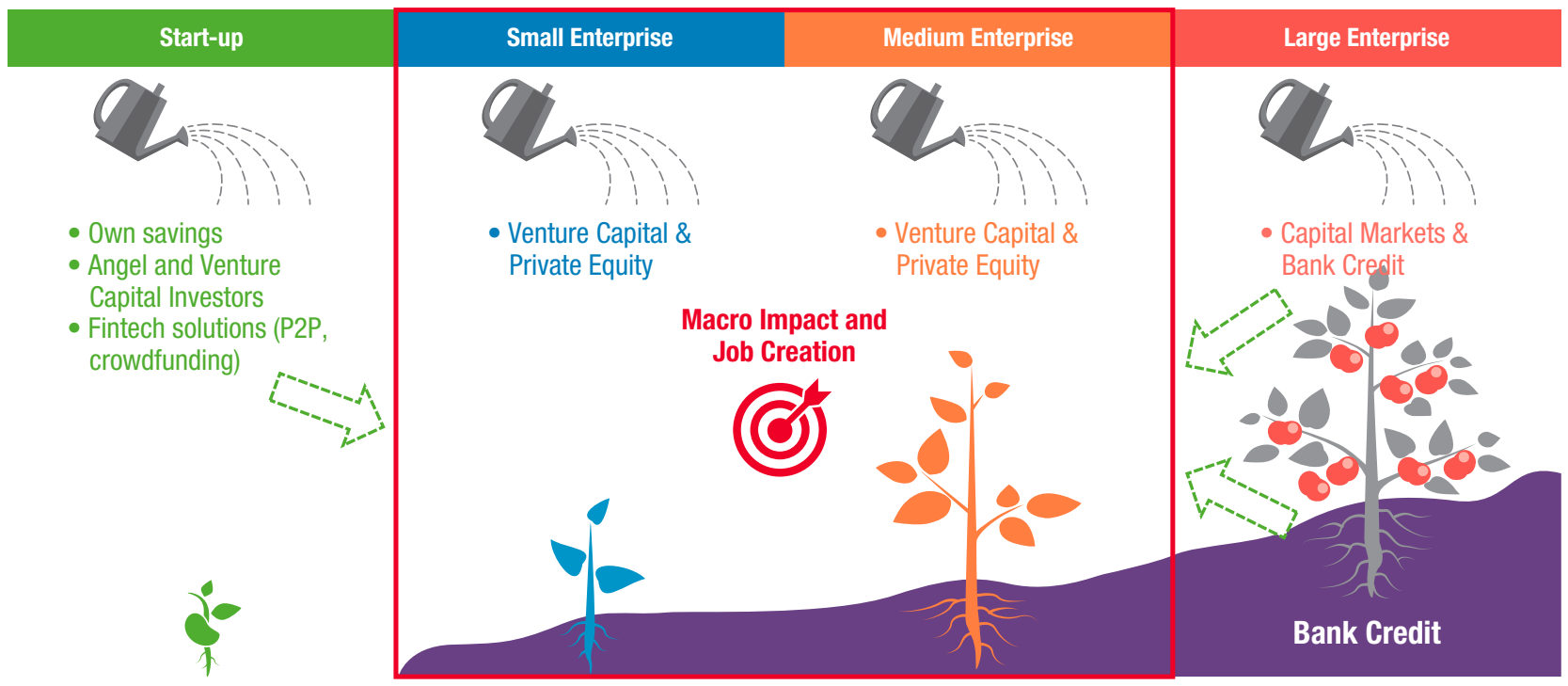

Source: IMF Staff.

Figure 13. SME Financing and Capital Markets

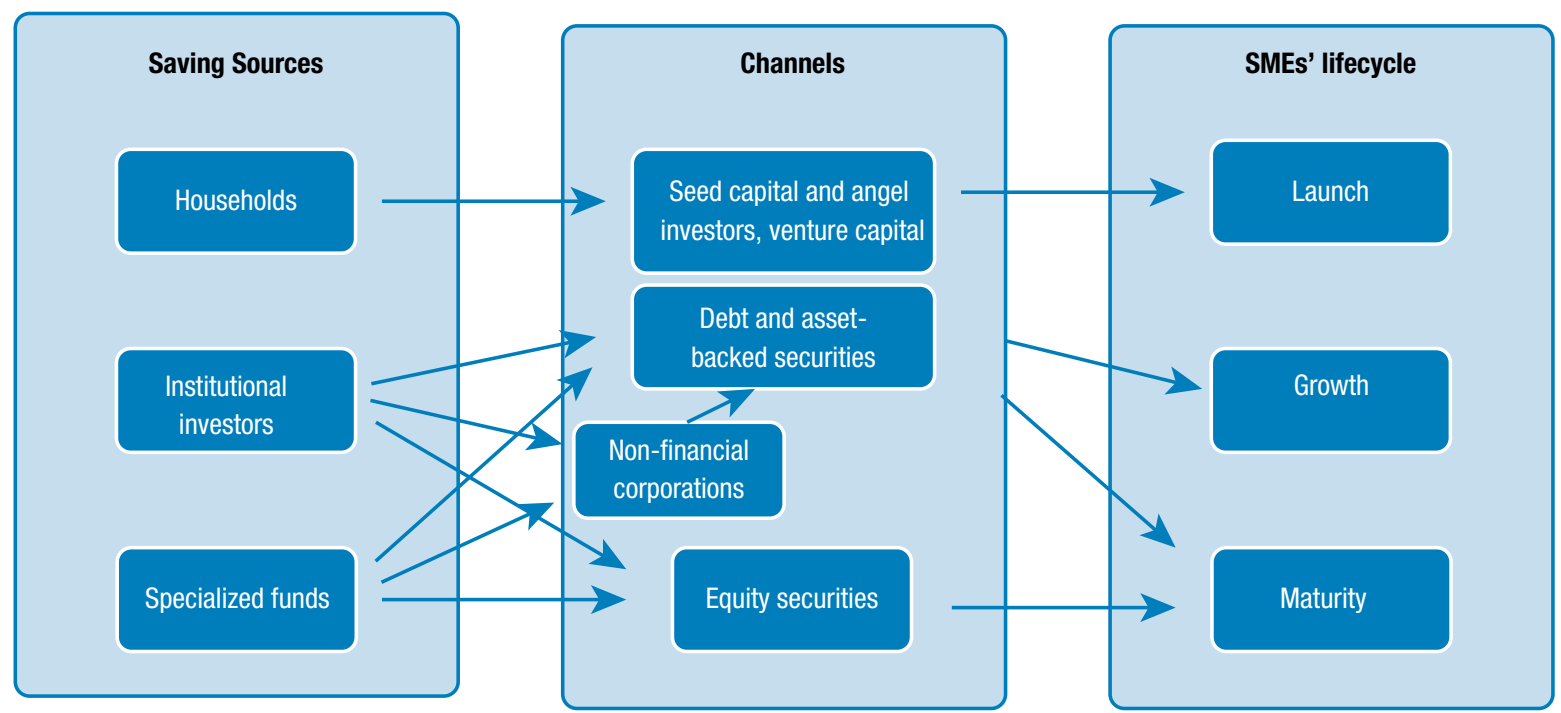

Source: IMF Staff. 
international standards (Figure 14). The size of institutional investors, including mutual funds, insurance companies, and pension funds, is comparatively limited, although some countries in the region (especially oil exporters) channel significant amounts of domestic savings through sovereign wealth funds. The availability of venture capital is also limited (IMF 2017d).

The development of SME capital market segments is hampered by the underdevelopment of broader capital markets in MENAP and CCA countries. In the region, capital markets, including credit and equity markets, are small relative to those in other regions. Bond issuance is for the most part limited to governments and large corporations.

A full ecosystem needs to be in place to support the development of different market segments and instruments serving SME financing needs. ${ }^{2}$ The requirements for such an ecosystem include fundamentals such as adequate macroeconomic policy frameworks and macroeconomic stability and, as noted, a large and diversified investor base and gradual development of broader capital markets. In addition, a range of institutional conditions also need to be in place, including financial infrastructure, legal frameworks, and regulatory and supervisory frameworks adapted to SMEs' specific needs. A list of key institutional issues, and examples of successful country experiences (including in the MENAP and CCA regions), are provided in Table 1. A country example shown in Box 3 illustrates the role of asset-backed securities in deepening credit markets and increasing SME lending capacity, including by attracting a broader set of investors to these assets. Box 4 describes a case of successful policies and regulatory flexibility to facilitate SMEs' access to equity markets through private placements on organized over-the-counter or exchange markets.

\section{Fintech}

Fintech is changing SME financing and has generated growing interest among policymakers. ${ }^{3}$ Developments in recent years illustrate the potential of fintech as an alternative source of financing. In the United Kingdom, for instance, four banks accounted for 80 percent of SME lending before the global financial crisis, and the supply of SME bank credit supply was sharply reduced during the crisis. In response, the authorities required banks that denied credit to SMEs to refer them to alternative lending providers,

\footnotetext{
${ }^{2}$ World Bank, IMF and OECD (2015), World Bank (2018).

${ }^{3}$ Fintech is defined by the Financial Stability Board as "Technologically-enabled financial innovation that could result in new business models, applications, processes or products with an associated material effect on financial markets, financial institutions and the provision of financial services" (FSB, 2017). See also Mills and McCarthy (2017).
} 
Figure 14. Capital Markets in the MENAP and CCA Regions

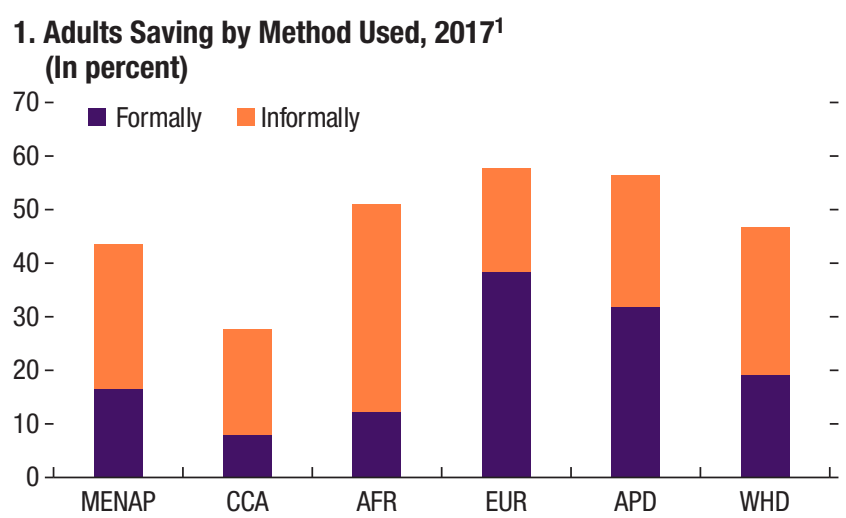

3. Insurance Company Assets, 2012-2016 $30-$ (In percent GDP)

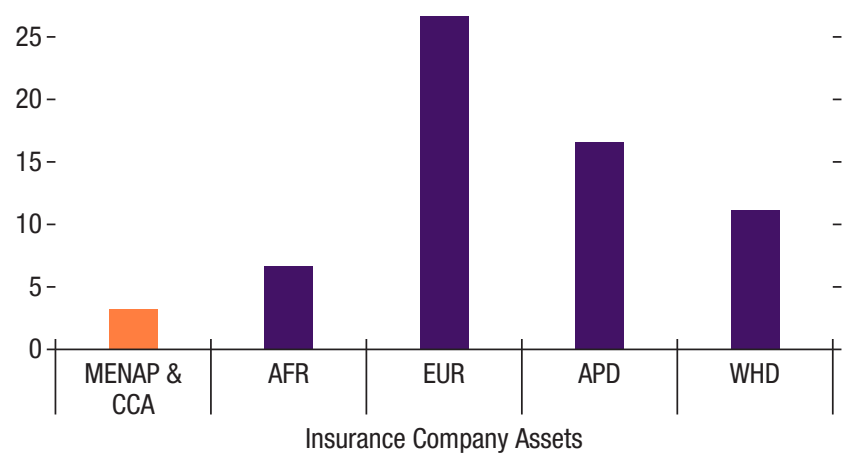

\section{Stock Market Capitalization²}

(In percent of GDP, average 2012-16) $150-$

$$
\begin{aligned}
& \text { Capitalization of Top } 10 \text { Largest Companies } \\
& \text { Rest } \\
& \text { MENAP Average }
\end{aligned}
$$

$100-$

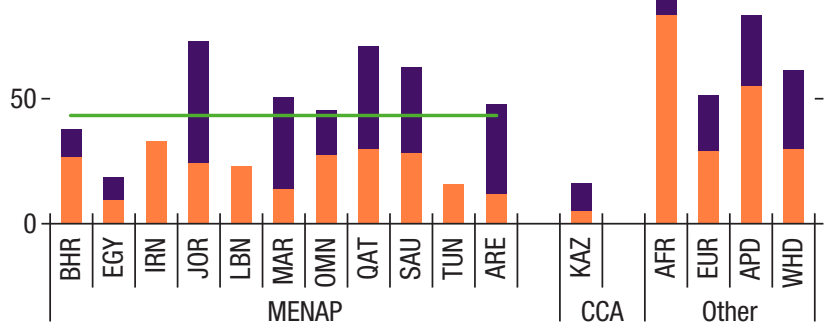

2. Mutual Fund and Pension Fund Assets, 2012-16 (In percent GDP)

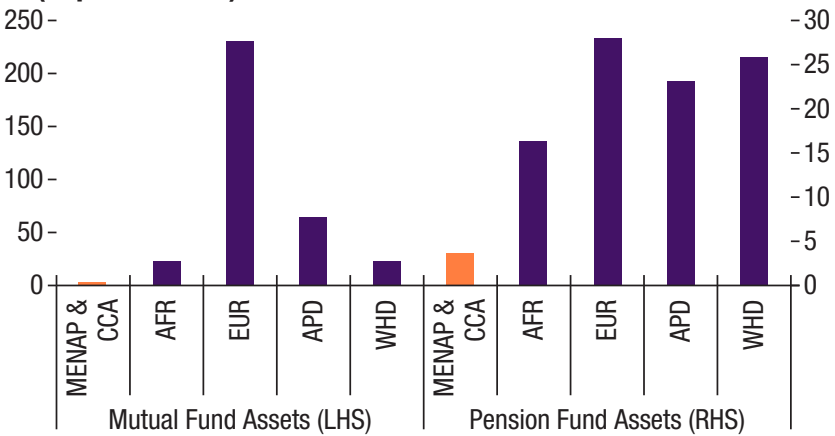

4. Sovereign Wealth Funds Total Assets, 2012-2017 (In percent GDP)

- MENAP \& CCA Average
6. Bond Issuance By Sectors, 2013-174 (In percent)

$$
\begin{gathered}
\text { State Authority } \\
\text {-government } \\
\text { Industries }
\end{gathered}
$$

MENAP \& CCA

Rest of the world (Excl. G7 countries)
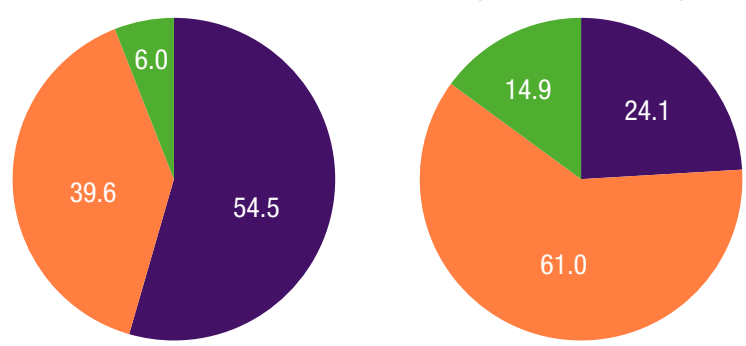

Sources: The Global Findex database 2017, Finstats 2018, Sovereign Wealth Fund Institute, Dealogic, and IMF staff estimates.

Note: Panels 4 and 5 use ISO country codes. MENAP = Middle East, North Africa, Afghanistan, and Pakistan; CCA = Caucasus and Central Asia; AFR = Africa, EUR = Europe; $A P D=$ Asia Pacific; $W H D=$ Western Hemisphere.

${ }^{1}$ Average calculated by regions with all data available in The Global Findex database 2017. Formal savings are saved at financial institutions.

${ }^{2}$ Average calculated with all the annual data points available in FinStats 2018 from 2012 to 2016.

3Updated June 2018. Average calculated with all the annual data points available from Sovereign Wealth Fund Institute.

${ }^{4}$ Concentrated industries: banking, telecommunications, oil coal gas, mining and energy utility. 
Table 1. Capital Markets Ecosystem for SMEs-Policies and International Practices
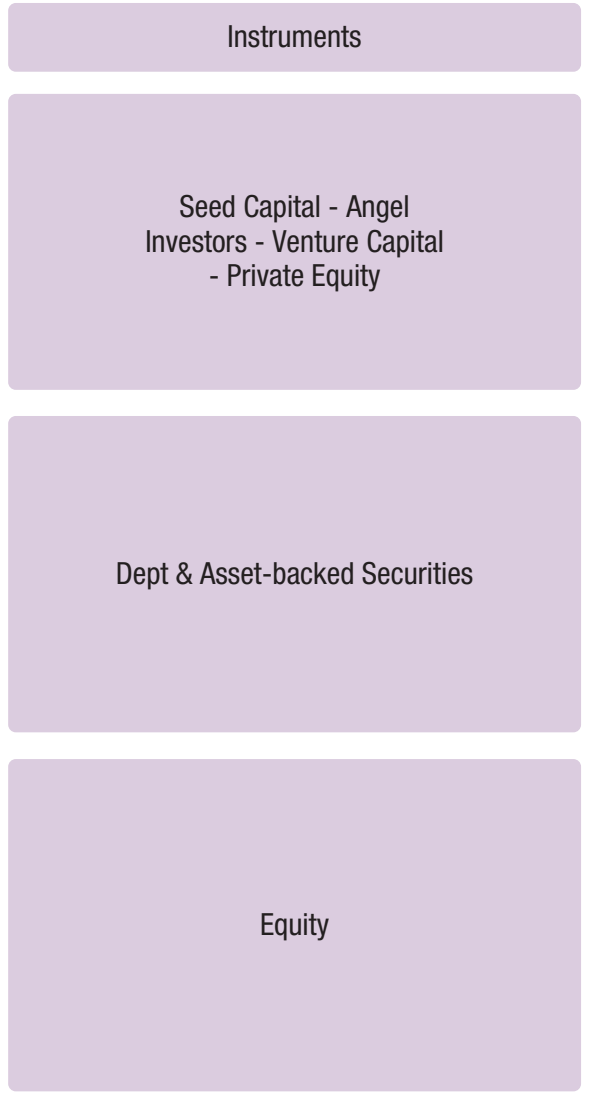

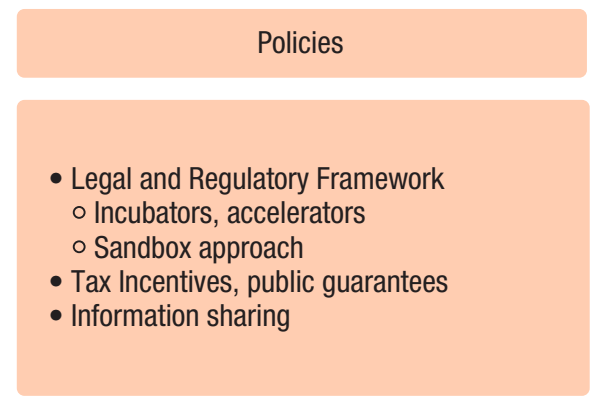

- Regulatory frameworks:

- Securities issuance (private, OTC, or exchange markets)

- Origination, standardization, and risk transfer (capital relief)

- Rating agencies

- Partial guarantees/Credit enhancements

- Fintech solutions (portfolio monitoring)

- Lower cost, proportionate regulatory requirements for issuance on SME-specific platforms

- SME corporate governance

(accounting and auditing standards)

- Financial literacy

\section{Cases worldwide and MCD}

- US: Global leader for venture capital

- Korea: government-based Korea Venture Capital Investment Corporation

- GCC: Venture capital

- Jordan and Lebanon: Public guarantees

- Kazakhstan: Regulatory reform

- Germany, Italy and Turkey:

SME covered bonds

- Peru: HMC Capital High Yield bond fund through the Alternative Securities Market

- Peru: Compass Fondo de Inversion para PYMEs - SME receivables securitization

- China: Alibaba ABS (Box 1)

- UK: SME-equity market segments AIM

- China: National Equities Exchange and Quotations

- Poland: NewConnect (Box 2)

- Egypt Nilex SME segment

- Bahrain Investment Market

- Pakistan Stock Exchange/SME Board

Source: IMF Staff.

\section{Box 3. Alibaba in China: SME Lending and Asset-Backed Securities}

Benefiting from its long-standing experience in SME lending and related proprietary data, the internet-based Chinese company Alibaba is securitizing its loan portfolio. Since it began, in 1999, the Alibaba Group has provided a range of services to SMEs through the internet to help them compete and grow. One of these services is lending, which has led to a loan portfolio of more than RMB 200 billion for more than 800,000 SMEs (IOSCO 2014). The success of this lending platform allowed the company to generate a large database both to monitor existing borrowers' credit performance and to screen prospective borrowers more effectively. In turn, this reduced significantly the origination and portfolio monitoring costs and allowed Alibaba to bundle these loans into asset-backed securities and to sell senior tranches to a broad set of investors on the Shenzhen Stock Exchange. In 2015, expanding the use of this technology, the Alibaba Group participated in the establishment of MYbank, an online bank specializing in SME lending, which by 2017 had extended RMB 441.3 billion in SME loans (Reuters 2018). 


\section{Box 4. NewConnect in Poland: SME Stock Exchange}

NewConnect is an alternative trading system for SMEs at the Warsaw Stock Exchange. SMEs generate about half of the Polish economy's value added (PARP 2014), and the development of long-term SME financing options was treated as a priority, especially after bank deleveraging following the global financial crisis reduced some of these options. Established in 2007 as an alternative trading system at the Warsaw Stock Exchange, NewConnect aims to facilitate SME equity issuance (World Bank 2015). It reduces entry requirements and costs and includes a private placement mechanism, which is used by most issuers. The presence of authorized advisors supervised by the Warsaw Stock Exchange helps to ensure regulatory compliance by issuers and to reduce information asymmetries for investors. The

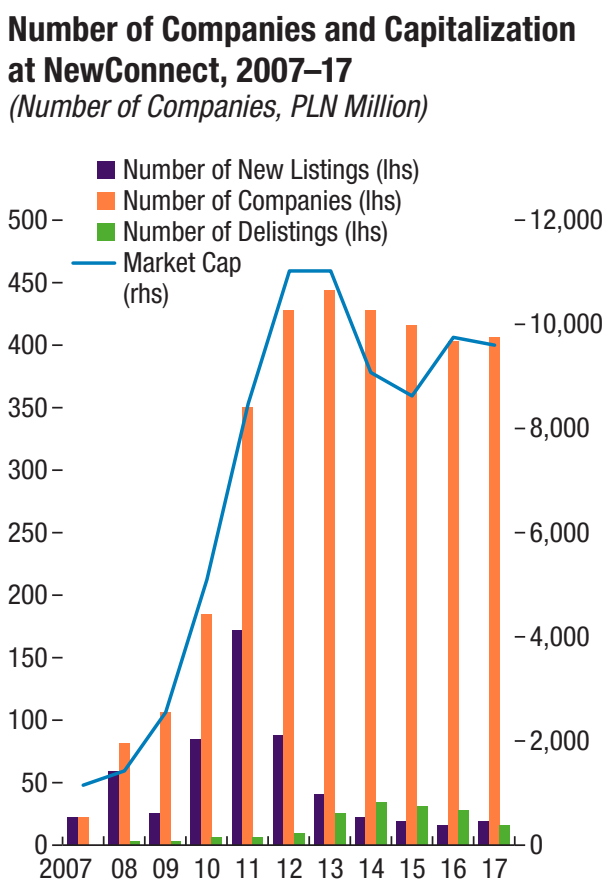

Sources: NewConnect Main Statistics; IMF staff estimates. number of listed companies and capitalization grew steadily until 2012 and has stabilized since then, and at least a quarter of the delisted companies had graduated to the main market by the end of 2017 .

which led to rapid growth in peer-to-peer lending, from fewer than 1 percent of new SME loans in 2014 to more than 3 percent by 2017. Fintech innovations can support SME financing, including credit provision and equity capital, both by facilitating bank credit supply and by opening new lending channels. ${ }^{4}$

\section{Enhancing Traditional SME Finance}

Several constraints to SME financial inclusion identified above could be reduced using new technologies. As noted, such constraints, especially in

${ }^{4} \operatorname{IMF}(2018 \mathrm{a})$. 
the MENAP and CCA regions, include lack of credit information, little competition and, more generally, the relatively high cost of servicing SMEs' financing needs.

Credit information is an area in which fintech is already supporting SME financing (Figure 15).

New technologies such as big data analytics and cloud computation facilitate the gathering and processing of large amounts of consumer credit performance and behavioral data (for example, from social media, psychometric information, and retail receipts). For SMEs, credit analysis can
Figure 15. Enhancing Traditional SME Finance

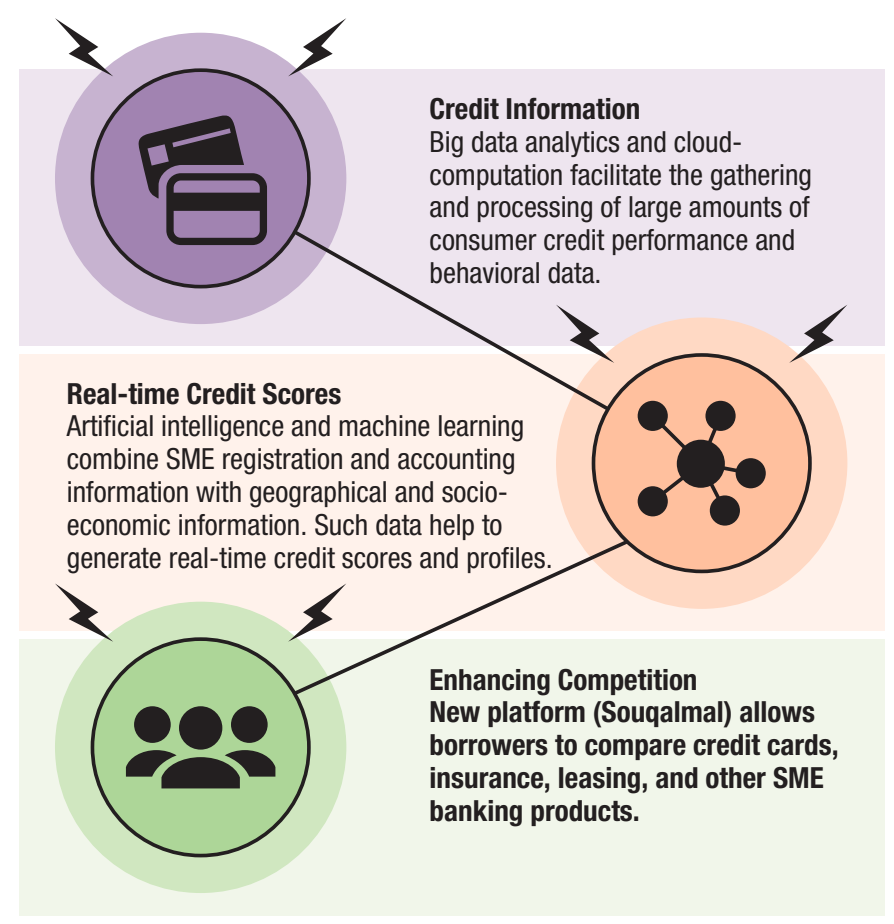

Source: IMF Staff. rely on artificial intelligence and machine learning that combine SME registration and accounting information with geographic and socioeconomic information. Such data help generate real-time credit scores and profiles and underpin stronger credit risk management. ${ }^{5}$ Similarly, blockchain technology can improve information management related to collateral registry and ownership and provide security, privacy, and transparency in decentralized open-source platforms.

Fintech can also play an important role in enhancing competition among providers of SME financial services. In the United Arab Emirates, a new platform (Souqalmal) allows borrowers to compare credit cards, insurance, leasing, and other SME banking products. Another promising area is the development of open banking platforms, where third-party providers access bank customer data to offer products with their consent. In the United King-

\footnotetext{
${ }^{5}$ Fintech-based credit scoring is used in mobile-data -based lending in Africa (Zoona), peer-to-peer SME lending in South Africa (Rainfin), and e-commerce lending in China (Zhima Credit). ShoBadge is an application that uses blockchain technology to provide enterprise-level identity authentication and an ecosystem for SME data management.
} 
Figure 16. Types of Fintech for SME Finance
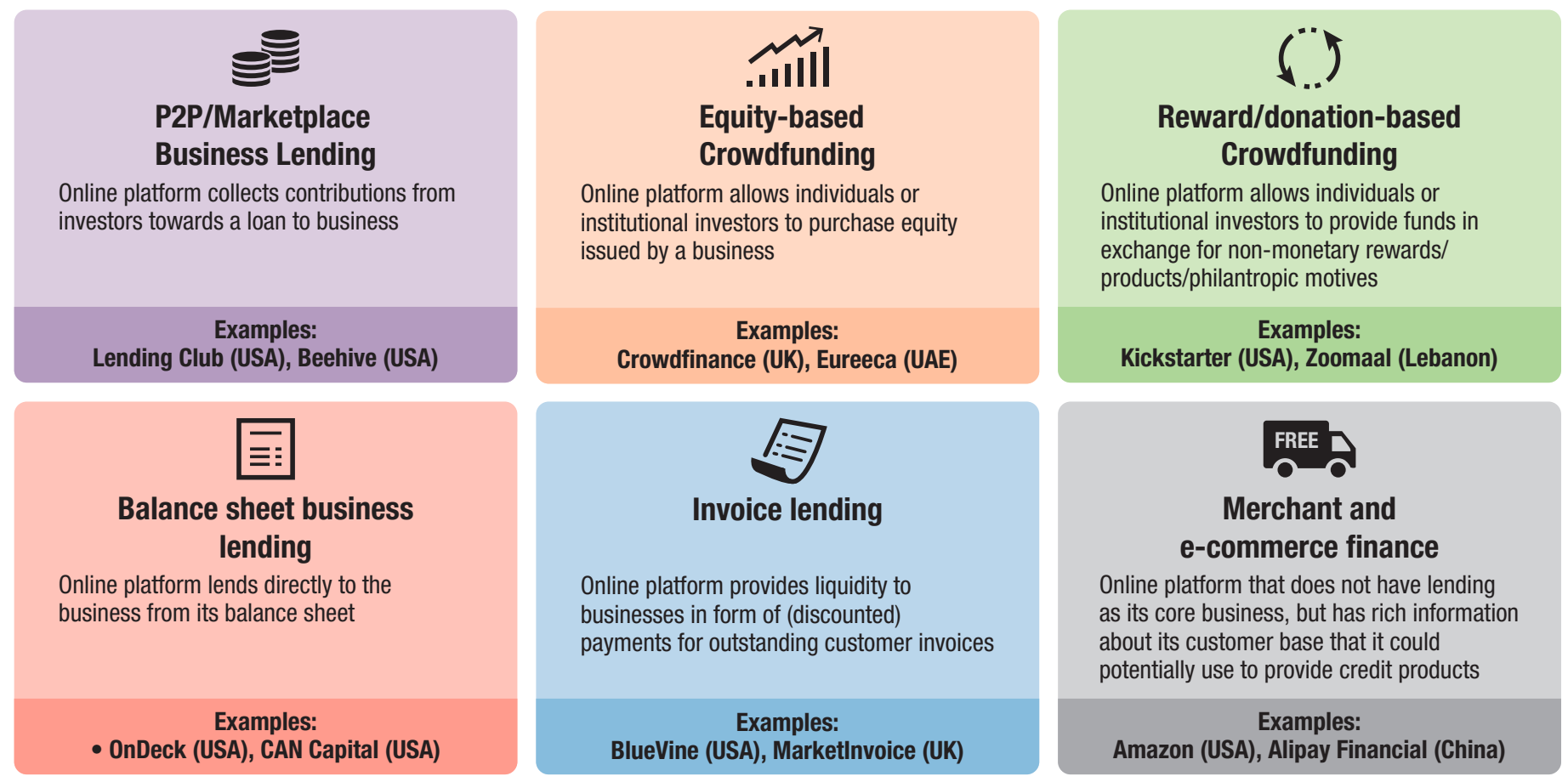

Source: IMF Staff.

dom, the nine largest banks were required to share SME data with external parties, helping to boost alternative lending channels. ${ }^{6}$

\section{Opening New Channels of SME Financing}

Fintech allows the development of alternatives to traditional (bank) SME lending. New electronic platforms have emerged that have led to a scaling up of crowdfunding, peer-to-peer lending, and other channels (Figure 16).

\section{Regulatory Technology (Regtech)}

New technologies can help lower regulatory compliance costs, which are a key obstacle to SME credit. Many banks in the MENAP and CCA regions need to perform AML/CFT due diligence for new accounts, which makes servicing SME accounts costlier. Fintech solutions offered by companies such as Suede and BearingPoint (Abacus) can reduce these and other compliance costs by embedding regulatory requirements into IT protocols and allow-

\footnotetext{
${ }^{6}$ U.K. Government, SME finance: help to match SMEs rejected for finance with alternative lenders, 2014.
} 
ing for real-time compliance monitoring. ${ }^{7}$ Know-your-customer and AML/ CFT procedures can also be made more efficient by analyzing digitalized client and partner transaction data and writing contracts on distributed ledgers (Trulioo).

\section{Fintech in the MENAP and CCA regions ${ }^{8}$}

Fintech is nascent in the MENAP and CCA regions, but its development has accelerated in recent years. Fintech investments are still low in both regions compared to global levels, but they are increasing rapidly in some countries. The UAE, Lebanon, Jordan and Egypt host three-fourths of the MENAP startups and have established large fintech accelerators. ${ }^{9}$ In the CCA region, fintech has been developing mostly in Kazakhstan. Fintech companies in both regions have focused primarily on payment solutions, marketplace lending, and crowdfunding, including for SMEs.

A combination of government and country-specific factors have played a role in fintech growth. In addition to the availability of private capital, fintech development has been boosted through government measures ranging from funding support to the establishment of attractive regulatory and legal framework for accelerators and incubators, and for foreign investors (UAE, Kazakhstan). In some countries, mistrust in traditional banking systems also contributed to the development of mobile payment solutions (e.g., in Afghanistan, Somalia, and Tajikistan).

A larger and well-regulated fintech sector would benefit MENAP and CCA countries. Both regions are characterized by a high share of youth and migrants in the population, increasing use of digital commerce, a large informal economy, and a strong need for economic and financial diversification. In this context, fintech could underpin greater financial inclusion of SMEs and underbanked population groups. However, demand for fintech-based SME finance remains largely unmet, and constraints identified by firms include: difficulties in hiring and retaining talent; the limited availability of private capital; and, low financial literacy. Legal and regulatory frameworks that address these constraints while protecting financial stability and consumer protection would help promote innovation and financial inclusion in both regions.

\footnotetext{
${ }^{7}$ Toronto Center (2017).

${ }^{8}$ Lukonga (2018).

${ }^{9}$ Green shoots include Bahrain-based PayTabs and Jordan-based ProgressSoft and eFAWATEERcom, which provide digital payment solutions for banks and SMEs. United Arab Emirates (UAE)-based Beehive and Eureeca, Lebanon-based Zoomaal, and Jordan-based Liwwa provide crowdfunding and peer-to-peer lending in the region.
} 


\section{Risks and Policy Initiatives}

Fintech introduces new risks into credit activities. ${ }^{10}$ Online platforms collect large quantities of data, creating risks for both data privacy and cybersecurity. Concerns about consumer protection and fraud are elevated, as instances of large-scale investor losses have already been observed. In addition, the resilience of technologies used by fintech lenders has not yet been tested through an entire economic cycle, and many lending platforms rely on short-term funding, which may aggravate the procyclicality of fintech credit institutions in times of liquidity pressure.

There is no single approach to fintech regulation, including in support of SME financing, but efforts to support cross-border coordination are underway. Regulatory responses range from the same standards as for other financial institutions to sector-specific regulation; many countries have not yet adopted a specific regulatory framework. Several jurisdictions (Singapore, United Arab Emirates, United Kingdom, among others) have introduced incubators - regulatory sandboxes, innovation hubs, and business accelerators - where fintech companies can test their models on a small scale. ${ }^{11}$ Many of these experiences are recent and still underway. The initiative by the Financial Conduct Authority of the United Kingdom to introduce a global sandbox to promote the harmonization of regulations and support the cross-border adoption of emerging technologies resulted in the Global Financial Innovation Network. ${ }^{12}$

A range of policy and institutional conditions are required to build fintech ecosystems (Figure 17). The initiatives mentioned here will help identify good practices, including for infrastructure, legal frameworks, regulatory environments, and other policies. For instance, regulation along categories of financial services provided rather than by types of fintech entities may emerge as a preferable approach to ensure full coverage of all participants and a level regulatory field. ${ }^{13}$ Some jurisdictions have been successful in initiating the development of fintech companies that provide SME financing (Box 5).

\footnotetext{
${ }^{10}$ For a comprehensive discussion on fintech credit and risks, see FSB (2017) and BIS (2018).

${ }^{11}$ For example, the Abu Dhabi Global Market (ADGM) financial free zone in the United Arab Emirates (UAE) works with start-up companies for two years on a limited license before they can apply for a full license.

${ }^{12}$ As of August 2018, the Global Financial Innovation Network (GFIN) is comprised of 12 regulatory bodies across the world, including the Abu Dhabi Global Market, Central Bank of Bahrain, and the Dubai Financial Services Authority.

${ }^{13}$ See IMF (2017b).
} 
Figure 17. Fintech Ecosystem
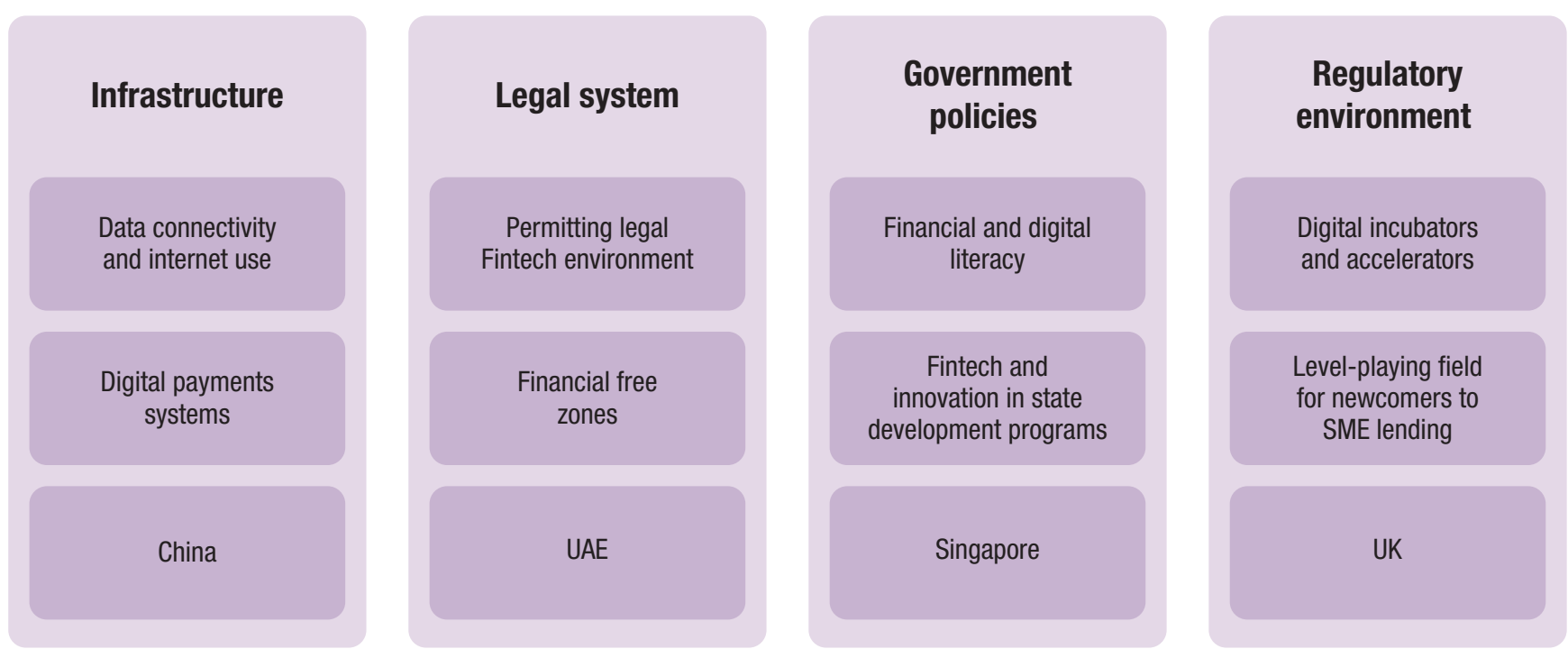

Source: IMF Staff.

\section{Box 5. Dubai International Financial Centre and Fintech Development}

The Dubai Financial Services Authority, as the financial regulatory agency of the special economic zone, the Dubai International Financial Centre, is leading efforts to develop and regulate fintech in the region. The Fintech Hive accelerator (the Hive) was launched in 2017 at the Dubai International Financial Centre, and the innovation testing license was developed by the financial services authority to allow start-up fintech companies to grow and test their products in a friendly regulatory environment. Some of the Hive cohorts' participants go on to receive licenses from the financial services authority.

The Dubai Financial Services Authority uses open-market consultations to develop regulations such as crowdfunding platform rules. In 2018, it joined the Global Financial Innovation Network initiative. As a result of these efforts, the Dubai International Financial Centre is today home to several successful fintech companies that provide SME financing, such as Eureeca (equity) and Beehive (a crowdfunding-based lending platform). 



\section{Chapter}

\section{Policy Strategies-Unlocking
SME Financial Inclusion}

Financial inclusion has been at the top of policy agendas in a growing number of countries. This recent international experience and the analyses here make it possible to identify key elements of reform strategies that will deliver more meaningful, safe, and sustainable access to financing for SMEs than partial policy approaches. Such holistic approaches can also trigger a virtuous circle of greater SME transparency and reduced informality, bringing about broader economic benefits.

\section{Current Policy Initiatives}

\section{Direct Intervention}

Countries have often relied on direct public intervention to boost SME financial inclusion, including in the MENAP and CCA regions. Such practices have ranged from targeted lending to SMEs by state-owned banks, to SME credit guarantees, to interest rate regulations.

State-owned banks tasked with supporting SME financial inclusion have played a role, but they should be subject to strong oversight. State-owned banks may enhance access to credit and play a countercyclical function in times of stress. However, they are frequently associated with low efficiency, concentration risk, high interconnectedness, politically directed lending, weak governance and asset quality, and regulatory forbearance. As such, key conditions for their success include regulation and supervision in the same manner as for private banks and assurance that they will not crowd out private credit.

Credit guarantee schemes have expanded since the global financial crisis, and a set of principles to guide their design has been introduced by the World 
Bank. ${ }^{1}$ There is some evidence that credit guarantee schemes contribute to financial inclusion in emerging market and developing economies and that they enable SME access to credit even during challenging times. ${ }^{2}$ However, they may also incur costs when they weaken credit discipline or crowd out unsecured loans. And they may not always meet the objective of generating additional or financially sustainable SME credit. ${ }^{3}$ A key issue is to ensure that credit guarantee schemes preserve market discipline in credit allocation. Therefore, they should be established as independent entities with clearly defined objectives and adequate funding, have a sound governance structure, adhere to strong credit risk management practices, and be properly supervised. Finally, the credit guarantee schemes' performance in terms of outreach, additionality, and financial sustainability should be evaluated and disclosed to the public. ${ }^{4}$

Although interest rate caps are still widely used, they often have unintended side effects. Interest rate caps are generally used to lower the overall cost of credit and to protect consumers from predatory lending. However, they also have unintended and potentially counterproductive effects (justifying the need to consider alternative measures to reduce the cost of credit). For instance, Ferrari, Masetti, and Ren (2018) present case studies indicating that interest rate caps often lead to lower credit supply and approval rates for small and risky borrowers, higher lending fees and commissions, less price transparency, fewer institutions and reduced branch density, and an adverse impact on bank profitability.

\section{Financial Inclusion Strategies}

A growing number of countries have introduced financial inclusion strategies in recent years. These strategies are often part of broader financial development strategies, and they may involve various types of government agencies. According to the World Bank's 2017 Global Financial Inclusion and Consumer Protection Survey, a quarter of countries have developed such strategies in recent years, and another quarter are preparing new ones. Certain national

\footnotetext{
${ }^{1}$ Harwood and Konidaris (2015).

${ }^{2}$ Calice (2016), Chatzouz and others (2017). OECD (2017) provides a comprehensive survey of the empirical literature and finds that credit guarantee schemes have a positive additional impact on firm finance and employment, but that the impact on firm performance is mixed, and that there are increased default risks.

${ }^{3}$ Abraham and Schmukler (2017).

${ }^{4}$ Outreach measures the credit guarantee scheme's (CGS) capacity to meet the demand by SMEs for guaranteed loans. It could be based at a minimum on the number of guarantees issued and on the total amount of outstanding guarantees. Additionality refers to financial additionality (extra credit extended) and economic additionality (extra employment, investment, and growth obtained). In practice, additionality is difficult to measure. Financial sustainability refers to the CGS's capacity to maintain an adequate capital base relative to its liabilities.
} 
financial sector strategies have been found overall to contribute significantly to greater financial sector deepening, inclusion, and stability. Experience shows that key factors for success include adequate coordination across government agencies, efforts by the leading governmental agency (in many cases, the central bank) to consult with the private sector, and regulatory reforms to promote better information sharing, contract enforcement, and insolvency regimes. 5

In the MENAP and CCA regions, the implementation of financial inclusion strategies has recently accelerated. Few MENAP and CCA jurisdictions responding to the 2017 World Bank survey had financial inclusion strategies in 2015-16. However, in the past few years, many have started to deploy such strategies and have undertaken important initiatives to improve the regulatory framework for financial access: ${ }^{6}$

- In 2016, Georgia introduced Georgia 2020, a development strategy supporting inclusive growth, including greater SME financial access. The government set up a comprehensive credit registry, revamped corporate accounting standards and insolvency procedures, and supported domestic capital market development. In parallel, the central bank and other public and private entities implemented a financial education strategy. Most recently, the authorities announced plans to ease SME access to financing through a credit guarantee scheme.

- Pakistan has implemented multiyear efforts to raise financial inclusion, including recently as part of the National Financial Inclusion Strategy 2016-20, one of whose objectives is to bring the share of SMEs in bank loans to the private sector to 15 percent by $2020 .^{7}$ For instance, a credit guarantee scheme was introduced for small farmers, with funding support from the government; the online credit information bureau has been continuously expanded and modernized; revised prudential regulations for SME financing have been issued; and a common technology has been developed to support the expansion of digital transaction accounts in rural areas.

- The central bank of Jordan issued in 2017 the National Financial Inclusion Strategy 2018-20, which aims to enhance financial inclusion, including for SMEs and through microfinance and digital financial services, as well as to promote financial literacy and strengthen financial consumer protection. In January 2016, a new credit bureau started compiling credit information, including for SMEs. Having accumulated three years of historical data, the bureau should soon be able to provide credit scores for SME borrow-

${ }^{5}$ Melecky and Podpiera (2018). Malaysia is an example where an SME agency was given strong coordination powers and was able to reach across jurisdictions to gain consensus on policy priorities.

${ }^{6} \mathrm{OECD}(2018)$.

${ }^{7}$ IMF (2017e). 
Figure 18. Framework for SME Financial Inclusion

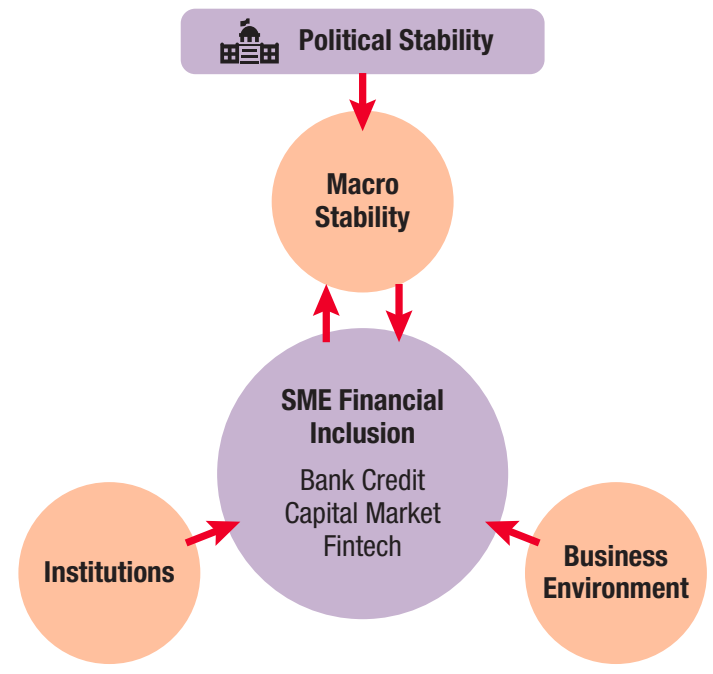

Source: Author's illustration. ers, which will help expedite credit risk assessments.

\section{Need for Holistic Policy Approaches}

The complex and interconnected factors that drive SME financial inclusion require holistic policy strategies. Previous sections of this paper show that a broad range of requirements must to be in place to unleash SME financing, including proper macroeconomic and financial policy frameworks, as well as legal and regulatory conditions that are critical to developing a strong SME credit culture and risk management practices. Efforts to promote safe and sustainable SME financial inclusion should therefore be part of policy strategies that are both comprehensive and tailored to country-specific circumstances. Such strategies are also likely to trigger a virtuous circle of greater SME transparency and reduced informality, bringing about broader benefits to the economy. In contrast, partial policy approaches, such as strategies focusing solely on direct public financing or guarantees, are unlikely to yield large or durable benefits.

The framework proposed in this paper can help inform the design of country-specific reform strategies for greater SME access to financing. Its building blocks, summarized in Figure 18, should be seen as mutually reinforcing and not just sequential. Various reforms can progress in tandem, especially if they reflect strategic prioritization based on each country's strengths and weaknesses across key policy areas. This framework can be further refined to help benchmark progress and identify specific reform priorities in individual countries. For instance, areas for further work could include the influence of various economic structures (for example, commodity exporting versus agriculture- or service-based economies); SME informality; interagency coordination (for policy consistency and to avoid unintended consequences); and supervisory practices and bankruptcy frameworks.

- Macro-financial and institutional requirements to scale up SME access to bank credit include limiting the relative size of the public sector (to avoid crowding out SME credit); macroeconomic stability; sound and competitive banking systems; competition in the economy more broadly; strong and stable institutions, including low corruption and political risk; sound 
financial regulatory and supervisory frameworks, with adequate incentives for SME financing; the availability of credit information; and strong legal frameworks (for example, for property rights, contract enforcement, collateralization, and insolvency).

- Policies to develop additional, alternative channels of SME financing include the development of capital market instruments to mobilize savings and channel them to SMEs (directly or through various financial intermediaries); a large and diversified investor base and broader capital market development; adequate financial infrastructure and legal frameworks; and regulatory and supervisory frameworks that support the safe development and integrity of capital markets and fintech-supported SME financing.

This framework can also help coordinate support from regional and international organizations in enhancing SME financial inclusion (Box 6). Key partners are multilateral development banks, intergovernmental organizations, standard setters, and private sector representative bodies. While some of these institutions directly provide or support financing to SMEs, all of them contribute to sharing policy lessons from international experience and identifying key challenges and priorities for SME financial inclusion across countries. 
Box 6. SME Financial Inclusion-Key Regional and International Organizations

The Arab Monetary Fund started an SME facility in 2016 for financial and technical assistance. It cosponsors the Financial Inclusion in the Arab Region Initiative, which supports the implementation of financial inclusion strategies in Arab countries.

The Asian Development Bank provides technical and financial assistance in support of SME development for its members. Its regional Access to Finance program offers financing to SMEs in Kazakhstan and Uzbekistan through partner banks.

The European Bank for Reconstruction and Development provides advice and lending to SMEs via its Small Business Initiative in the MENAP and CCA region, typically through partnerships with local financial institutions, and increasingly in local currency.

The European Investment Bank is a major provider of SME financing via its European Investment Fund and its SME Initiative, including in the Middle East and Central Asia region.

The International Finance Corporation provides advisory services to support financial intermediaries and equity, credit, and mezzanine financing to institutions that lend to SMEs. It has a dedicated website on SME development (http://www .smefinanceforum.org).

The International Organization of Securities Commissions supports capital market development, including for SME financing, and has had a task force on financing of SMEs since 2012 that produces analysis on capital markets and other sources of SME financing.

The Islamic Development Bank recently launched Transform Fund, which provides seed money to innovative start-ups. It also partnered with the African Development Bank to jointly finance projects, including in the SME area. The Islamic Financial Services Board disseminates good practices for sharia-compliant SME financing, including through banks and crowdfunding.

The Multilateral Investment Guarantee Agency provides credit enhancement guarantees in support of private equity funds and capital market development. Its Small Investment Program facilitates medium- and long-term lending to SMEs.

The Organization for Economic Co-operation and Development supports SME financing via the MENA-OECD Enterprise Financing Network by providing a common platform for entrepreneurs, financiers, researchers, and regulators. It publishes regular cross-country reviews on the state of entrepreneurship and SME development. 


\section{Box 6. SME Financial Inclusion-Key Regional and International Organizations (continued)}

The Union of Arab Banks hosts the annual Arab SME forum, which brings together regional policymakers and private sector representatives. It also runs the Access to SME Finance survey in cooperation with the World Bank.

The World Bank provides advisory and lending services to develop financial sector infrastructure and SME lending. It is leading the Consultative Group to Assist the Poor, which brings together international financial institutions to advance financial inclusion, including for SMEs. More broadly, the World Bank is a major source of research and analysis on SME development and financial inclusion. 



\section{Annex 1. Methodology for the SME Financial Inclusion Index}

The SME financial inclusion index reduces multidimensional data from the World Bank Enterprise Survey to a summary index using the following steps: (1) normalization of variables; (2) aggregation of normalized variables into sub-indices by principal component analysis, using the first component; and (3) aggregation of the subindices into the final index. Several choices need to be made in constructing the index. In the World Bank Enterprise Survey, several questions are designed to evaluate financial conditions for firms. From these, the variables most relevant to bank financing conditions were chosen (listed below) and divided into categories of access and usage. This index is available for 119 countries worldwide, of which 20 are in the MENAP and CCA regions. The index captures the observed SME financial inclusion that reflects the equilibrium of supply and demand for financial services for SMEs. As shown in the figures below, it correlates strongly with alternative measures of SME financial inclusion, with the share of partially of fully credit-constrained SMEs (Kuntchev and others, 2014), and with the share of SMEs with rejected loans (which highlights the importance of supply-side constraints that are the main focus of the paper). 
Annex Figure 1.1. SME Financial Inclusion Index

Percent of firms with a bank loan/line of credit

Percent of firms with a checking or savings account

Percent of firms using banks to finance investments

Percent of firms using banks to finance working capital

Proportion of investments financed by banks (in percent)

Proportion of working capital financed by banks (in percent)
$(0.42)$
$0.9-$

$$
0.8-
$$

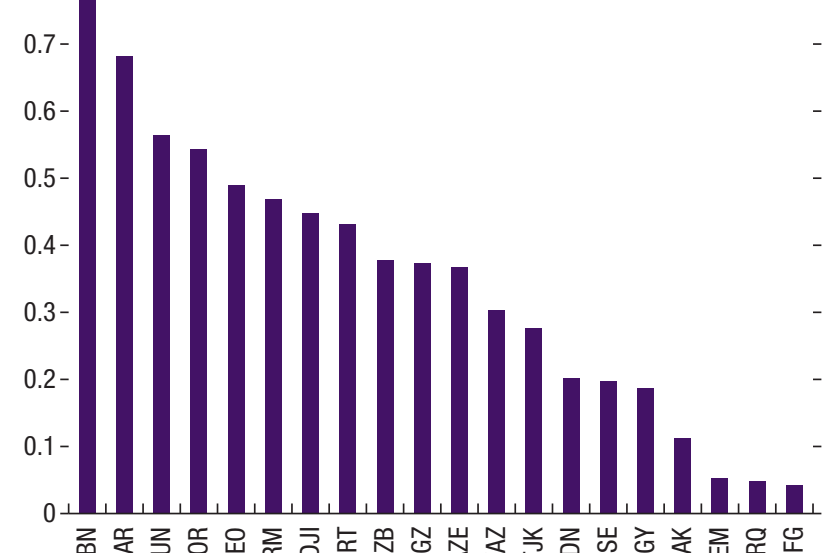

Sources: World Bank Enterprise Surveys, IMF Staff calculations.

Annex Figure 1.2. SME Financial Inclusion, Credit Constraints and Rejected Loan

1. SME Financial Inclusion Index versus Kutchet et al. (2014) Index

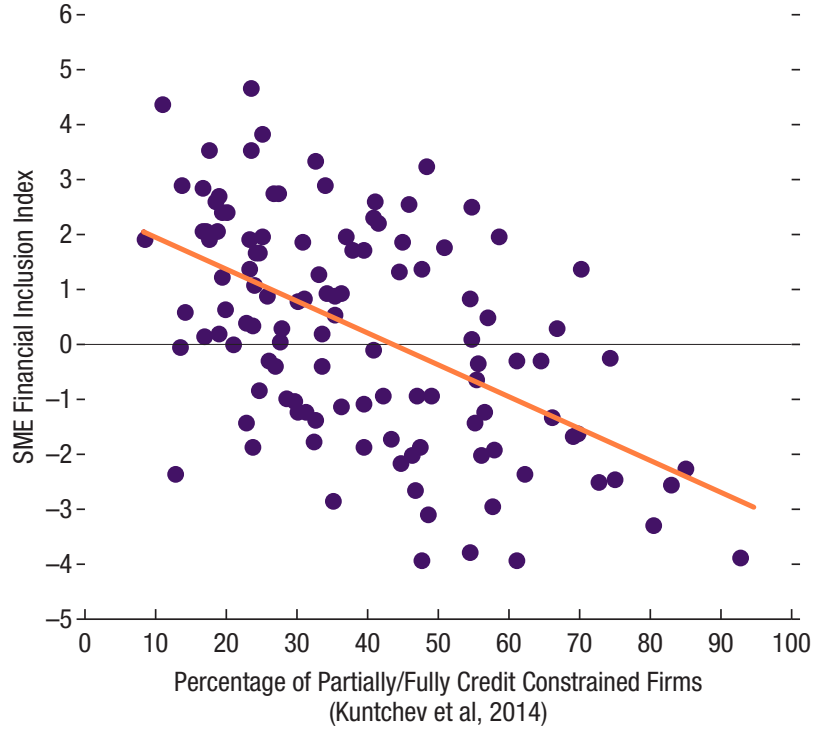

\section{SME Financial Inclusion Index versus Share of SMEs with Rejected Loans}

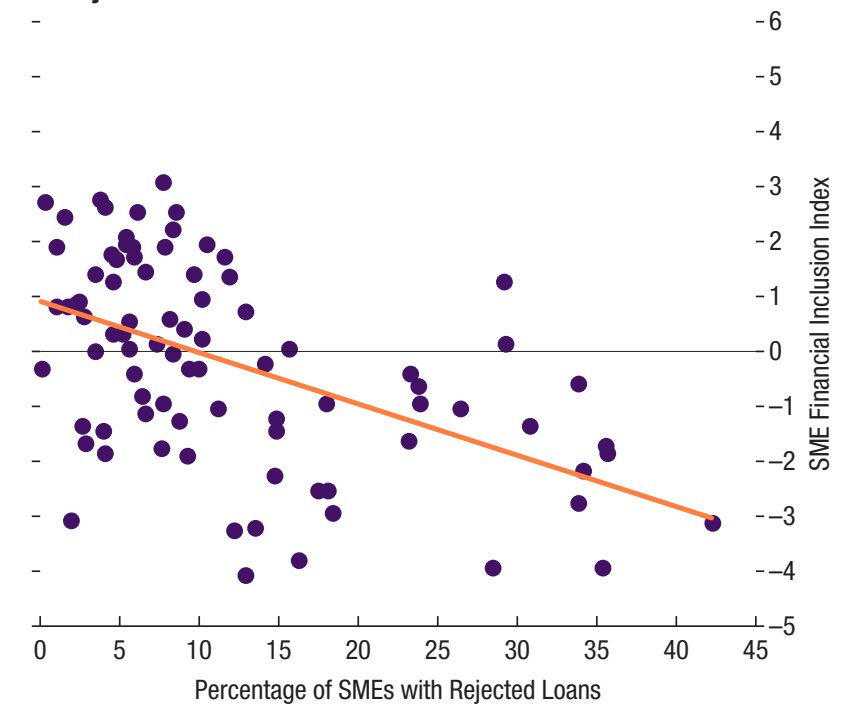

Sources: Kuntchev and others (2014), World Bank Enterprise Surveys, IMF Staff calculations. 


\section{Annex 2. SME Financial Inclusion Gap}

Financial inclusion is driven mainly by macroeconomic and institutional fundamentals. In the following table, financial inclusion is linked to these fundamentals: ${ }^{1}$

- Economic development (income per capita), which captures country characteristics such as quality of infrastructure, education, and health

- Governance (control of corruption)

- Credit information availability (coverage of credit registries)

- Economic competition (proxied by the share of small firms in the private sector)

- Business environment, including contract enforcement

The SME financial inclusion gaps are calculated as the difference between countries' actual financial inclusion level and that of the country at the 90th percentile.

\begin{tabular}{|c|c|}
\hline Variables & $\begin{array}{c}\text { (1) } \\
\text { Model } 1\end{array}$ \\
\hline Log of PPP GDP per capita & $\begin{array}{l}0.0773^{\star \star *} \\
(0.00951)\end{array}$ \\
\hline Time required to enforce a contract (days) & $\begin{array}{c}-0.000130^{\star \star \star *} \\
(0.00004)\end{array}$ \\
\hline Small-firm share of total firms & $\begin{array}{c}-0.207^{\star \star} \\
(0.09470)\end{array}$ \\
\hline Control of corruption: estimate & $\begin{array}{l}0.0709^{\star \star \star} \\
(0.02450)\end{array}$ \\
\hline Public credit registry coverage (\% of adults) & $\begin{array}{l}0.00429^{\star \star \star} \\
(0.00143)\end{array}$ \\
\hline Observations & 119 \\
\hline$R$ squared & 0.912 \\
\hline
\end{tabular}

\footnotetext{
${ }^{1}$ Indicators of governance (rule of law) and financial openness should be interpreted with caution due to a limited number of respondents, limited geographical coverage, and standardized assumptions on business constraints and information availability. They indicators may also not reflect more recent structural changes.
} 



\section{Annex 3. Growth and Employment Benefits of Increased Access to Financing for SMEs}

The relationships between SME access to financing, unemployment, and growth are examined using static and dynamic panel regression frameworks.

Real GDP growth is linked to SME financial inclusion (financial inclusion index and SME bank loans) while controlling for other factors that are likely to affect growth, human capital, the macroeconomic environment, and the quality of institutions. The impact of financial inclusion on unemployment is estimated using a similar framework.

The following equations were estimated:

(1) Growth $_{i t}=\alpha+\beta F I_{i t}+\lambda X_{i t}+\gamma_{i}+\varphi_{t}+\varepsilon_{i t}$

(2) Unempl $l_{i t}=\alpha+\beta F I_{i t}+\lambda X_{i t}+\gamma_{i}+\varphi_{t}+\varepsilon_{i t}$

where Growth is real GDP, Unempl is unemployment, FI is the measure of SME financial inclusion (the financial inclusion index or bank loans to SMEs), ${ }^{1} X$ is a vector of control variables, $\gamma_{i}$ and $\varphi_{t}$ are country and time fixed effects (respectively), and $\varepsilon_{i t}$ is the error term. $i$ and $t$ indicate country and year, respectively.

Equations (1) and (2) were first estimated using ordinary least squares panel fixed effects and generalized least squares (GLS) estimators. GLS with $\mathrm{AR}(1)$ correction take into account the possibility of a strong autocorrelation between unemployment and GDP growth data. To overcome a potential endogeneity bias affecting these estimates, dynamic general method of

A more detailed discussion is provided in Appendino and others (IMF Working Paper, forthcoming).

${ }^{1}$ Data on loans to SMEs offer a longer time series (compared with the financial inclusion index), which allows for implementation of the dynamic generalized method of moments. 
moments estimations (Arellano and Bond 1991; Blundell and Bond 1998) were also performed. Given the limited availability of external instruments, this estimation method relies on an internal instrumentation approach in which the endogenous variables are instrumented with their lags. To further check the robustness of the results, some specifications include private credit to GDP as an additional control variable. This helps separate more precisely the impact of SME lending from that of lending to the broader private sector.

Annex Table 3.1. Employment Benefits of SME Financial Inclusion

\begin{tabular}{|c|c|c|c|c|c|}
\hline \multirow[b]{2}{*}{ Variables } & \multicolumn{5}{|c|}{ Dependent variable: unemployment rate (log) } \\
\hline & $\begin{array}{l}\text { (1) } \\
\mathrm{FE}\end{array}$ & $\begin{array}{l}\text { (2) } \\
\text { GLS }\end{array}$ & $\begin{array}{l}\text { (3) } \\
\text { GLS }\end{array}$ & $\begin{array}{c}\text { (4) } \\
\text { GMM }\end{array}$ & $\begin{array}{l}\text { (5) } \\
\text { GMM }\end{array}$ \\
\hline Loans to SMEs (log) & $\begin{array}{c}0.0169 \\
(0.0222)\end{array}$ & $\begin{array}{c}-0.0700^{\star \star \star} \\
(0.0140)\end{array}$ & $\begin{array}{c}-0.045^{\star \star \star} \\
(0.014)\end{array}$ & $\begin{array}{c}-0.136^{\star \star \star} \\
(0.0472)\end{array}$ & $\begin{array}{c}-0.131^{\star \star \star \star} \\
(0.042)\end{array}$ \\
\hline Education (log) & $\begin{array}{c}-0.212 \\
(0.241)\end{array}$ & $\begin{array}{c}0.226^{*} \\
(0.125)\end{array}$ & $\begin{array}{l}0.279^{\star \star} \\
(0.131)\end{array}$ & $\begin{array}{c}-0.162 \\
(0.205)\end{array}$ & $\begin{array}{r}-0.278 \\
(0.185)\end{array}$ \\
\hline GDP (log) & $\begin{array}{c}-0.448^{\star \star \star} \\
(0.0633)\end{array}$ & $\begin{array}{l}0.00755 \\
(0.0345)\end{array}$ & $\begin{array}{c}-0.012 \\
(0.034)\end{array}$ & $\begin{array}{c}-0.230^{\star \star} \\
(0.106)\end{array}$ & $\begin{array}{c}-0.234^{\star \star \star} \\
(0.072)\end{array}$ \\
\hline Population (log) & $\begin{array}{l}0.810^{\star \star \star} \\
(0.278)\end{array}$ & $\begin{array}{c}0.00976 \\
(0.0335)\end{array}$ & $\begin{array}{c}0.006 \\
(0.034)\end{array}$ & $\begin{array}{c}0.297 \\
(0.225)\end{array}$ & $\begin{array}{c}0.350 \\
(0.226)\end{array}$ \\
\hline Inflation (log) & $\begin{array}{c}-0.0394^{\star \star \star} \\
(0.0130)\end{array}$ & $\begin{array}{r}-0.00763 \\
(0.00838)\end{array}$ & $\begin{array}{c}-0.008 \\
(0.008)\end{array}$ & $\begin{array}{r}-0.0144^{\star *} \\
(0.00717)\end{array}$ & $\begin{array}{c}-0.021^{\star \star \star \star} \\
(0.005)\end{array}$ \\
\hline Lagged unemployment rate (log) & & & & $\begin{array}{c}0.269^{\star \star \star} \\
(0.0283)\end{array}$ & $\begin{array}{l}0.274^{\star \star \star} \\
(0.042)\end{array}$ \\
\hline Credit to GDP (log) & & & $\begin{array}{c}-0.094^{\star \star \star} \\
(0.034)\end{array}$ & & $\begin{array}{c}0.084 \\
(0.053)\end{array}$ \\
\hline Constant & $\begin{array}{c}-8.863^{\star \star} \\
(4.462)\end{array}$ & $\begin{array}{l}1.768^{\star \star \star} \\
(0.639)\end{array}$ & $\begin{array}{l}1.972^{\star \star \star} \\
(0.650)\end{array}$ & & \\
\hline Hansen $P$ value & & & & 0.232 & 0.250 \\
\hline Observations & 326 & 325 & 324 & 273 & 273 \\
\hline$R$ squared & 0.349 & & & & \\
\hline Number of countries & 38 & 37 & 37 & 37 & 37 \\
\hline $\begin{array}{l}\text { Source: IMF staff calculations. } \\
\text { Note: Standard errors are in paren } \\
\text { incorporate AR(1) correction. The I } \\
\text { using too many instruments. } P \text { val } \\
\text { reported. FE = fixed effects. } \\
{ }^{\star \star \star} p<0.01 ;{ }^{* \star} p<0.05 ;{ }^{*} p<0 .\end{array}$ & $\begin{array}{l}\text { ountry and ye } \\
\text { ruments for } g \\
\text { ansen test of } 0\end{array}$ & $\begin{array}{l}\text { ffects are incl } \\
\text { method of } \mathrm{m} \\
\text { ying restrictiol }\end{array}$ & $\begin{array}{l}\text { not reported. } \\
\text { the null hyp }\end{array}$ & $\begin{array}{l}\text { zed least squar } \\
\text { laximum of fou } \\
\text { lat the instrum }\end{array}$ & $\begin{array}{l}\text { estimates } \\
\text { avoid } \\
\text { valid) are }\end{array}$ \\
\hline
\end{tabular}


Annex Table 3.2. Growth Benefits of SME Financial Inclusion

\begin{tabular}{|c|c|c|c|c|c|c|}
\hline \multirow[b]{2}{*}{ Variables } & \multicolumn{4}{|c|}{ Dependent variable: real GDP growth } & \multicolumn{2}{|c|}{ Real GDP (log) } \\
\hline & $\begin{array}{l}\text { (FE) } \\
(1)\end{array}$ & $\begin{array}{l}\text { (GLS) } \\
(2)\end{array}$ & $\begin{array}{c}\text { (GMM) } \\
\text { (3) }\end{array}$ & $\begin{array}{c}\text { (GMM) } \\
\text { (4) }\end{array}$ & $\begin{array}{l}\mathrm{FE} \\
\text { (5) }\end{array}$ & $\begin{array}{l}\mathrm{FE} \\
(6)\end{array}$ \\
\hline Loans to SME growth & $\begin{array}{l}0.00516 \\
(0.005)\end{array}$ & $\begin{array}{l}{ }_{0.01067^{\star * \star}} \\
(0.003)\end{array}$ & $\begin{array}{l}{ }_{0.08298^{\star \star \star}} \\
(0.023)\end{array}$ & 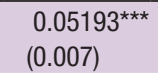 & & \\
\hline SME financial inclusion index (log) & & & & & $\begin{array}{l}0.056^{\star *} \\
(0.023)\end{array}$ & $\begin{array}{l}0.060^{\star *} \\
(0.024)\end{array}$ \\
\hline Gross fixed $\mathrm{K}$ formation growth & $\begin{array}{l}0.00035^{\star \star \star} \\
(0.000)\end{array}$ & $\begin{array}{l}0.00039^{* * *} \\
(0.000)\end{array}$ & $\begin{array}{l}0.00028 \\
(0.001)\end{array}$ & & $\begin{array}{c}-0.001 \\
(0.001)\end{array}$ & \\
\hline Health \& education & $\begin{array}{l}0.00013 \\
(0.000)\end{array}$ & $\begin{array}{l}0.00022^{\star *} \\
(0.000)\end{array}$ & $\begin{array}{l}0.00130^{\star *} \\
(0.001)\end{array}$ & $\begin{array}{l}0.00026 \\
(0.000)\end{array}$ & $\begin{array}{l}0.124^{\star \star *} \\
(0.044)\end{array}$ & $\begin{array}{l}0.103^{\star \star} \\
(0.043)\end{array}$ \\
\hline Voice \& accountability & $\begin{array}{l}0.05089^{* \star *} \\
(0.018)\end{array}$ & $\begin{array}{c}-0.00262 \\
(0.003)\end{array}$ & $\begin{array}{c}-0.01819 \\
(0.020)\end{array}$ & $\begin{array}{l}0.01416^{\star \star} \\
(0.006)\end{array}$ & $\begin{array}{l}0.368^{\star \star *} \\
(0.095)\end{array}$ & $\begin{array}{l}0.361^{\star \star *} \\
(0.111)\end{array}$ \\
\hline Political stability & $\begin{array}{l}0.00623 \\
(0.010)\end{array}$ & $\begin{array}{l}0.00174 \\
(0.002)\end{array}$ & $\begin{array}{l}0.00121 \\
(0.021)\end{array}$ & $\begin{array}{c}-0.00500 \\
(0.005)\end{array}$ & $\begin{array}{r}-0.018 \\
(0.052)\end{array}$ & $\begin{array}{c}-0.034 \\
(0.055)\end{array}$ \\
\hline Inflation & $\begin{array}{l}-0.00067^{\star \star \star} \\
(0.000)\end{array}$ & $\begin{array}{c}-0.00052^{\star \star *} \\
(0.000)\end{array}$ & $\begin{array}{l}0.00066 \\
(0.001)\end{array}$ & $\begin{array}{l}0.00049^{*} \\
(0.000)\end{array}$ & $\begin{array}{c}0.001 \\
(0.002)\end{array}$ & $\begin{array}{c}0.001 \\
(0.004)\end{array}$ \\
\hline Money growth & $\begin{array}{l}0.00190^{\star \star \star} \\
(0.000)\end{array}$ & $\begin{array}{l}0.00125^{\star \star *} \\
(0.000)\end{array}$ & $\begin{array}{l}0.00062 \\
(0.001)\end{array}$ & $\begin{array}{l}0.00166^{\star \star \star} \\
(0.000)\end{array}$ & $\begin{array}{l}0.009^{\star \star \star} \\
(0.002)\end{array}$ & \\
\hline Global competitiveness & $\begin{array}{l}-0.00117^{\star \star \star} \\
(0.000)\end{array}$ & $\begin{array}{l}-0.00041^{\star * \star} \\
(0.000)\end{array}$ & $\begin{array}{c}-0.00147 \\
(0.001)\end{array}$ & $\begin{array}{l}-0.00081^{\star * *} \\
(0.000)\end{array}$ & $\begin{array}{c}-0.003^{\star \star \star} \\
(0.001)\end{array}$ & $\begin{array}{r}-0.003 \\
(0.002)\end{array}$ \\
\hline 2007-09 global financial crisis & $\begin{array}{l}-0.03242^{\star \star \star} \\
(0.005)\end{array}$ & $\begin{array}{l}-0.02836^{\star \star \star} \\
(0.004)\end{array}$ & $\begin{array}{l}-0.03729^{\star \star \star} \\
(0.009)\end{array}$ & $\begin{array}{l}-0.03635^{\star \star \star} \\
(0.002)\end{array}$ & $\begin{array}{c}-0.167^{\star \star \star} \\
(0.019)\end{array}$ & $\begin{array}{r}-0.114^{*} \\
(0.062)\end{array}$ \\
\hline Low income & $\begin{array}{l}0.04194^{\star} \\
(0.023)\end{array}$ & $\begin{array}{l}0.04049^{\star \star *} \\
(0.009)\end{array}$ & $\begin{array}{c}-0.05051 \\
(0.076)\end{array}$ & $\begin{array}{l}0.09595^{\star \star \star} \\
(0.013)\end{array}$ & $\begin{array}{l}0.148^{\star * *} \\
(0.047)\end{array}$ & $\begin{array}{c}0.084 \\
(0.066)\end{array}$ \\
\hline Lower middle income & 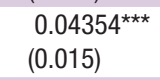 & $\begin{array}{l}0.04067^{\star * *} \\
(0.008)\end{array}$ & $\begin{array}{c}-0.06293 \\
(0.051)\end{array}$ & $\begin{array}{l}0.06238^{\text {*** }} \\
(0.010)\end{array}$ & $\begin{array}{l}0.189^{\star \star *} \\
(0.029)\end{array}$ & $\begin{array}{l}0.119^{\star \star \star} \\
(0.036)\end{array}$ \\
\hline Upper middle income & $\begin{array}{l}0.02215^{\star *} \\
(0.010)\end{array}$ & $\begin{array}{l}0.01809^{\star \star \star} \\
(0.006)\end{array}$ & $\begin{array}{c}-0.06221 \\
(0.041)\end{array}$ & $\begin{array}{l}0.03459^{\star \star \star} \\
(0.009)\end{array}$ & $\begin{array}{l}0.235^{\star \star *} \\
(0.016)\end{array}$ & $\begin{array}{l}0.148^{\star \star \star} \\
(0.026)\end{array}$ \\
\hline Private credit (log) & & & & $\begin{array}{c}-0.00016 \\
(0.002)\end{array}$ & & $\begin{array}{l}0.051 \\
(0.093)\end{array}$ \\
\hline Lagged real GDP growth & & & $\begin{array}{l}0.76060^{\star \star *} \\
(0.260)\end{array}$ & $\begin{array}{l}0.20632^{\star \star *} \\
(0.032)\end{array}$ & & \\
\hline Constant & $\begin{array}{l}0.07976^{\star \star \star} \\
(0.024)\end{array}$ & $\begin{array}{l}0.02693^{\star \star \star} \\
(0.004)\end{array}$ & $\begin{array}{l}0.04838 \\
(0.051)\end{array}$ & $\begin{array}{l}0.01672 \\
(0.019)\end{array}$ & $\begin{array}{l}6.626^{\star \star \star} \\
(0.290)\end{array}$ & $\begin{array}{l}6.499^{\star \star \star} \\
(0.748)\end{array}$ \\
\hline Observations & 302 & 300 & 302 & 316 & 104 & 103 \\
\hline$R$ squared & 0.259 & & & & 0.986 & 0.985 \\
\hline Number of countries & 46 & 44 & 46 & 48 & 89 & 89 \\
\hline Wald test $P$ value & & . & 0 & 0 & & \\
\hline Hansen $P$ value & & 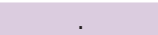 & 0.244 & 0.691 & & \\
\hline
\end{tabular}

Source: IMF staff calculations.

Note: Standard errors are in parentheses. Country and year fixed effects are included but not reported. Generalized least squares (GLS) estimates incorporate AR(1) correction. The list of instruments for generalized method of moments (GMM) is limited to the maximum of four lags to avoid using too many instruments. $P$ values of Hansen test of overidentifying restrictions (to test the null hypothesis that the instruments are valid) are reported. ${ }^{* \star *} p<0.01 ;{ }^{* \star} p<0.05 ;{ }^{*} p<0.1$. 



\section{Annex 4. Benefits from Relaxing Constraints on SME Financial Inclusion: Country-Specific Analysis}

Using the dynamic stochastic general equilibrium (DSGE) model in Dabla-Norris and others (2015b), we analyzed specific financial inclusion constraints facing individual countries and the possible macroeconomic impact of their relaxation. ${ }^{1}$

Sample: Based on World Bank Enterprise Survey data, the sample covers six MENAP countries (Egypt, Jordan, Lebanon, Morocco, Pakistan, Tunisia) and seven CCA countries (Armenia, Azerbaijan, Georgia, Kazakhstan, Kyrgyz Republic, Tajikistan, Uzbekistan).

Overview of simulated results: Limited financial inclusion could weigh on economic prosperity by discouraging productive firms or forcing them to operate below optimal scale owing to insufficient financing. These are the key variables used to assess constraints to SME financial access:

- Fixed financial access cost $(\psi)$ incorporates several factors that prevent entrepreneurs from accessing credit, including asymmetric information; higher cost of serving the SME sector; and limited financial literacy, which affects SME credit demand. Relaxing these constraints could significantly boost the share of firms with access to credit and raise economic potential. Countries such as Egypt, Pakistan, and Uzbekistan could improve long-term output by several percentage points by mitigating such constraints.

- Collateral requirements $(\lambda)$ limit borrower moral hazard and contribute to greater financial stability. However, they may also force small entrepreneurs (with few resources of their own to put down as collateral) out of the market or to operate at a suboptimal scale. In countries such as Armenia and

\footnotetext{
${ }^{1}$ Results from the model should be interpreted carefully. For instance, the model applies the same probability of failure $(p)$ to all entrepreneurs, irrespective of their talent or firm size. As a result, greater financial inclusion does not lead to riskier credit portfolios, which in some cases may not be a realistic assumption.
} 
Georgia, policies to loosen collateral constraints could help reap significant benefits from greater SME financial inclusion.

- Monitoring cost $(\chi)$ captures how efficiently banks can assess credit risk (including collateral recovery), which contributes to the margin between interest rates applied to highly leveraged borrowers and the cost of funding (savings rate). Low interest rate margins encourage highly productive SMEs to expand their production toward the optimal scale. However, they may also lead to excessive risk taking and rising nonperforming loans. This channel appears to have a relatively small macroeconomic impact for countries in the sample. 


\section{Annex Figure 4.1. Stylized Facts and Model Simulation}

Part I. Financial Inclusion Indicators ${ }^{1}$

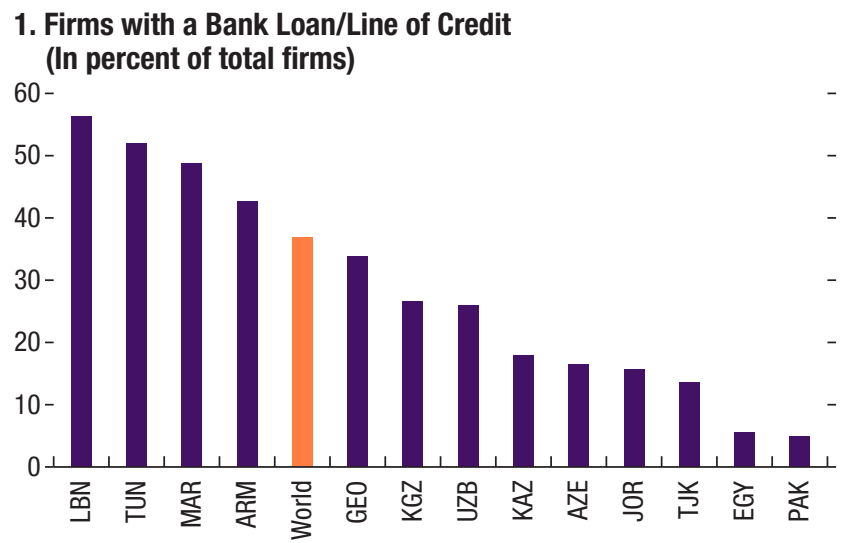

\section{Lending-Deposit Interest Rate Spread} $25-$ (In percent)

\section{Value of Collateral Needed for a Loan (In percent of the loan amount)}

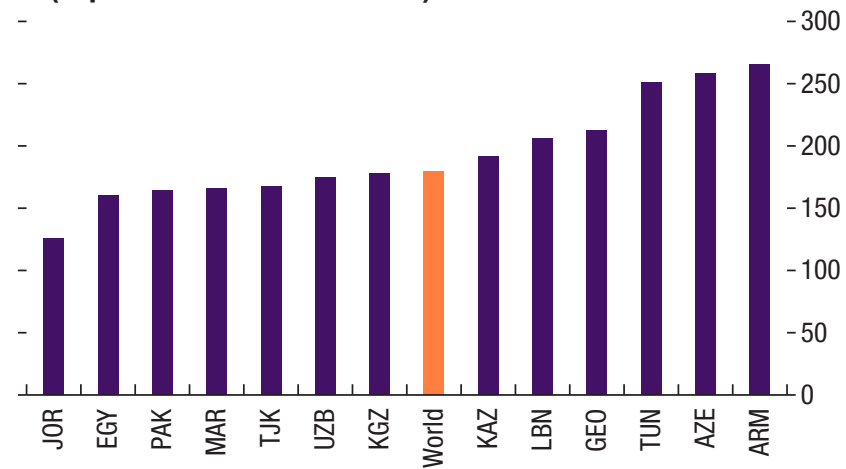

\section{Nonperforming Loans (In percent of total loan portfolio)}

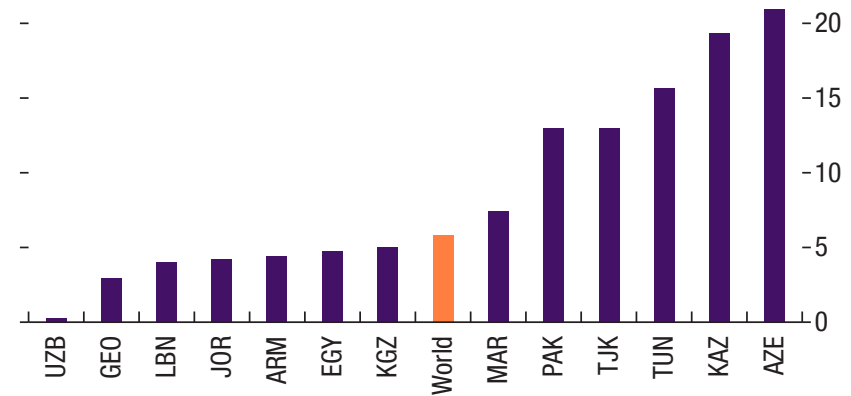

Part II. Model Simulated Comparative Statics: MCD Average ${ }^{2,3}$

— Reducing monitoring cost — Relaxing collateral constraint $\quad$ - Reducing financial access cost

\section{Gross Domestic Product}

(Ratio relative to the most constraint case) $1.15-$

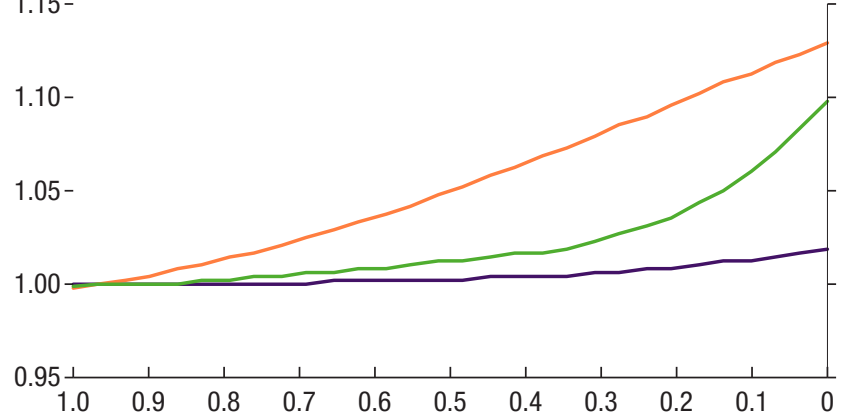

\section{Total Factor Productivity}

(Ratio relative to the most constraint case)

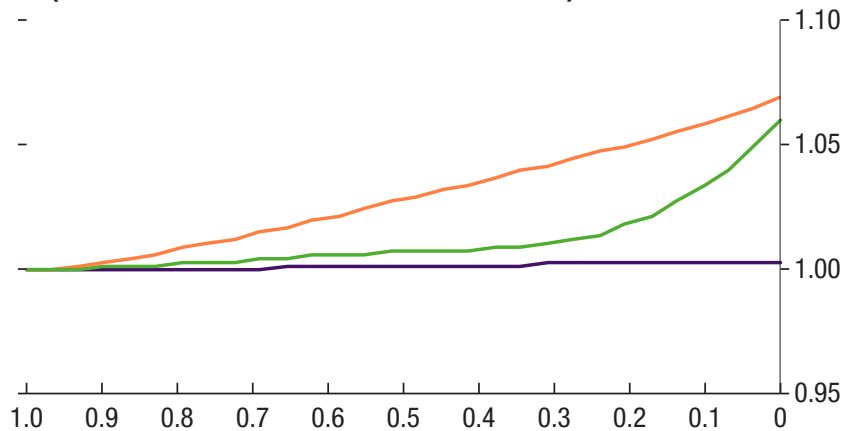

Sources: World Bank Enterprise Survey, World Development Indicators, and IMF staff calculation.

Note: ISO country codes are used for abbreviations. MENAP = Middle East, North Africa, Afghanistan, and Pakistan; CCA = Caucasus and Central Asia; MCD = Middle East and Central Asia.

${ }^{1}$ World average is calculated based on information for all country-year combination for which an enterprise survey has been conducted. The survey covers mainly emerging markets and low-income countries.

${ }^{2} \mathrm{MCD}$ aggregate is constructed using simulated comparative statics for six MENAP countries (Egypt, Jordan, Lebanon, Morocco, Pakistan, and Tunisia) and seven CCA countries (Armenia, Azerbaijan, Georgia, Kazakhstan, Kyrgyz Republic, Tajikistan, and Uzbekistan). Simulation is done using the most recent World Bank Enterprise Survey data. Individual country outcome is weighted by relative GDP share computed using 2013 nominal GDP in U.S. dollar.

${ }^{3}$ Horizontal axis shows the magnitude of three financial frictions, normalized to be between 0 (least constraining case) and 1 (most constraining case). Parameter for monitoring cost $(\mathrm{X})$ ranges from 0.5 (implying a lending-deposit spread as high as 60 percent in some countries) and 0 (implying almost zero spread). Collateral requirement is captured by leverage ratio $(\lambda)$-calculated inclusive of collateral which varies between 1 (no borrowing) and 2 (borrowing allowed up to the amount of collateral). Financial access cost $(\psi)$ varies from 3 (share of firms with credit approaching 0 percent) to 0 (share of firms with credit approaching 100 percent). 



\section{Annex 5. Access to Financing and Firm-Level Employment, Sales, and Productivity Growth}

To assess the impact of access to financing on firm-level employment and labor productivity growth in MENAP and CCA countries, we employ the following specification, as in Ayyagari and others (2016), using data from the World Bank Enterprise Surveys: ${ }^{1}$

$$
\Delta E_{i j t}=\alpha F_{i j t}+B X_{i j t}+Z_{j t}+C_{j}+Y_{t}+\varepsilon_{i j t},
$$

where $\Delta E_{i j t}$ is the annual employment (or labor productivity) growth for firm $i$ in country $j$ in year $t ; F_{i j t}$ is an indicator variable capturing whether a particular firm in a particular country surveyed in a particular year had a formal loan outstanding; $X_{i j t}$ and $Z_{j t}$ are firm-level and country-level controls, respectively; $C_{j}$ and $Y_{t}$ are country and year fixed effects. We estimated separately for (1) SMEs and large firms to test whether employment gains from access to financing are larger for smaller firms, and for (2) SMEs only. The results are consistent with our hypotheses. The point estimates for $\alpha$ are positive and statistically significant with $p$-values below 10 percent for each of them, and their relative magnitudes are consistent with our hypotheses regarding firm size as well (see Figure 3).

We used the point estimates for SMEs to estimate macroeconomic gains from SME financial inclusion through a simple growth accounting exercise. This suggests that the additional 1.3 percent in SME employment growth, added to a gain from augmented labor productivity of 2.3 percent (with a labor share equal to two-thirds) implies an additional 1 percent of GDP growth. Such an increase in employment represents about 16.5 million new jobs in MENAP and CCA countries (14.3 million in MENAP and 2.3 million in CCA) by 2025 above the baseline employment projection that follows the

\footnotetext{
${ }^{1}$ The data cover Armenia, Azerbaijan, Djibouti, Egypt, Georgia, Iraq, Jordan, Kazakhstan, Kyrgyz Republic, Lebanon, Morocco, Tajikistan, Tunisia, Uzbekistan, and Yemen, for different years from 2008 to 2016.
} 
average annual growth rate from 2012 to 2017 (using employment data from the International Labour Organization).

Finally, we explore the introduction of credit bureaus as a supply-side policy change following Ayyagari and others (2016). For this, we replace $F_{i j t}$ in the above equation with $C B_{j t}$, a proxy for SME credit bureau coverage based on the share of adults covered by credit bureaus (using data from the World Bank's Doing Business Indicators). The results are consistent with the finding that financial inclusion has a positive impact on employment growth, with SMEs being a key driver. ${ }^{2}$ We used the point estimates of $\alpha$ to calculate the average employment growth gains from closing the credit bureau coverage gap with respect to the average emerging market and developing economy and to the average advanced economy for countries in our sample that are below each of these thresholds (see Figure 8).

${ }^{2}$ The $\alpha$ point estimate for SMEs is similar to that for the overall sample, with similar statistical significance. 


\section{Annex 6. SME Financial Inclusion and Macroeconomic Policy}

To test the link between macroeconomic policies and SME financial inclusion, we separate MENAP and CCA countries into those with high and low SME financial inclusion, estimate two separate panel vector autoregressions at the country level, and test if the estimates for those with higher SME financial inclusion present dynamics consistent with more effective policy. We include the countries for which we have the needed annual macroeconomic time series from 1990 to 2017, using Haver Analytics data and the SME financial inclusion index as in Annex $1 .^{1}$

In the case of fiscal policy, we explore the link between SME financial inclusion and the efficiency of tax collection. We estimate the following panel vector autoregression separately for firms in the top and bottom quartiles of SME financial inclusion:

$$
Y_{i t}=A Y_{i t-1}+u_{i}+v_{t}+e_{i t}
$$

where $Y=\left\{\frac{T a x}{G D P}\right.$, output gap, inflation $\}$, which gives the recursive ordering for identifying structural shocks. We measure the efficiency of tax collection as the impulse response of $\frac{\operatorname{Tax}}{G D P}$ to a structural positive shock to the output gap. The result confirms the hypothesis that SME financial inclusion makes tax collection more effective: high-financial-inclusion countries present a statistically significant (at 10 percent level) first lag response, but the same parameter is not statistically significant for low-financial-inclusion countries. ${ }^{2}$

\footnotetext{
${ }^{1}$ Countries covered are Armenia, Azerbaijan, Egypt, Georgia, Iraq, Jordan, Kazakhstan, the Kyrgyz Republic, Lebanon, Morocco, Tajikistan, Tunisia, Uzbekistan, and Yemen.

${ }^{2}$ Top and bottom halves did not present statistically significant results.
} 
We test the strength of monetary policy transmission estimating the same panel vector autoregression following Mehrotra and Yetman (2014) and IMF (2018a), with the same equation as above but with $Y=$ \{output gap, inflation, nominal interest rate\}. In this case, the recursive ordering for identifying structural shocks allows us to measure the strength of monetary transmission by the magnitude of the impulse response of the output gap to a 100 basis point structural shock to the nominal interest rate, which, as in the case of fiscal policy, is statistically significant at the 10 percent level only for the high-financial-inclusion countries. The ratio of the variance of the output gap to inflation is higher for the group of countries with higher SME financial inclusion, providing evidence in support of the hypothesis that SME financial inclusion strengthens monetary policy effectiveness (see Figure 4). 


\section{Annex 7. Drivers of SME Financial Inclusion}

This analysis aims to (1) identify the main determinants of SME access to formal (bank) financial services and (2) provide evidence about key constraints to SME financial inclusion in MENAP and CCA countries specifically. The empirical tests rely on the following two equations:

(1) $F I_{i t}=\alpha+\beta X_{i t}+\lambda$ region_dummy $+\rho z_{i t}+\varepsilon_{i t}$

(2) $F I_{i t}=\alpha+\beta X_{i t}+\lambda$ region_dummy $+\delta$ region_dummy* $z_{i t}+\rho z_{i t}+\varepsilon_{i t}$

where the dependent variable (FI) is the composite index of SME financial inclusion. $\mathrm{X}$ is a vector of control variables that includes total investment (in percent of GDP), inflation, SME share of employment (in percent of total employment), and the level of economic development. The region dummy is either a CCA or MENAP dummy variable, which takes the value of 1 for MENAP or CCA countries and 0 otherwise. Both equations are estimated with CCA and MENAP dummies, separately. The baseline specification is extended to control successively for additional characteristics $(z)$ capturing ${ }^{1}$

- Broader macroeconomic environment: diversification, informality, competition, quality of infrastructure, saving behavior, interest rate restrictions, public investment (percent of total investment), fiscal balance, and an oil-exporter country dummy. ${ }^{2}$

A more detailed discussion is provided in Ndoye and others (IMF Working Paper, forthcoming).

${ }^{1} \mathrm{~A}$ larger set of controls was tested. This appendix only reports only on the variables that were found to have a statistically significant relationship with SME financial inclusion.

${ }^{2}$ Diversification is proxied by the Economic Complexity Index (OECD); infrastructure by the share of telephone lines in the population, and, informality by the share of the shadow economy (in percentage of total GDP). 
- Quality of institutions: voice and accountability, political stability, government effectiveness, and control of corruption.

- Banking sector characteristics: return on equity, asset quality (nonperforming loan ratios), bank deposits, banking sector stability, and banking sector concentration.

- Business environment: taxation (percent of profit), cost of starting a business and registering property, time to enforce a contract, public credit registry coverage, and property rights.

Equation (1) describes a linear relationship between financial inclusion and its determinants, while equation (2) explores potential nonlinearities, especially with respect to the MENAP region. Both equations are estimated using ordinary least squares. Annex Figure 7.1 provides some preliminary stylized facts on the governance and structural characteristics across regions. Overall, the MENAP and CCA regions generally perform poorly compared with their peers. Annex Figures 7.2 and 7.3 report the estimated coefficients (statistically significant at the 10 percent level or lower) for the full sample as well as specifically for the MENAP and CCA regions. 
Annex Figure 7.1. Selected Governance and Structural Indicators

1. Voice and Accountability

$1.5-$
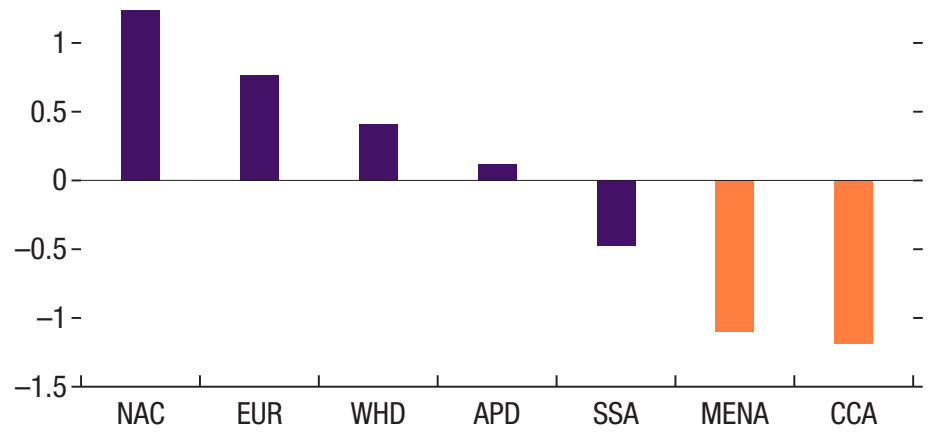

3. Control of Corruption

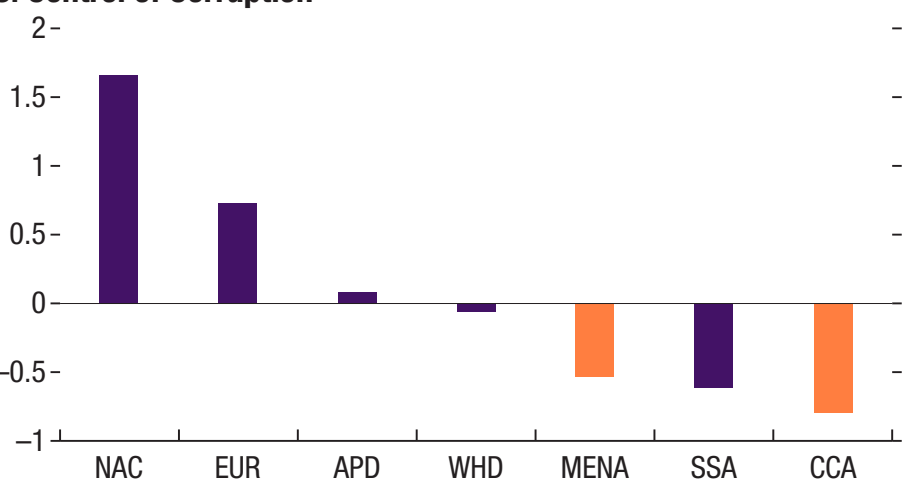

7. Infrastructure

35

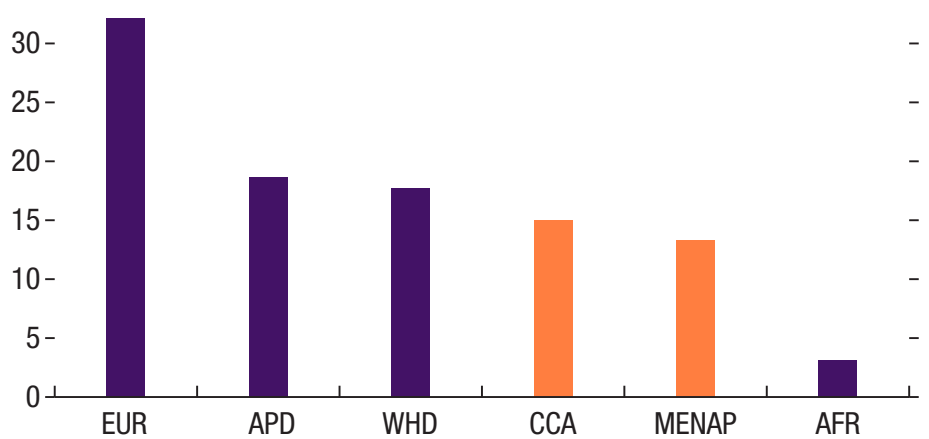

2. Political Stability and Absence of Violence/Terrorism

$-1$
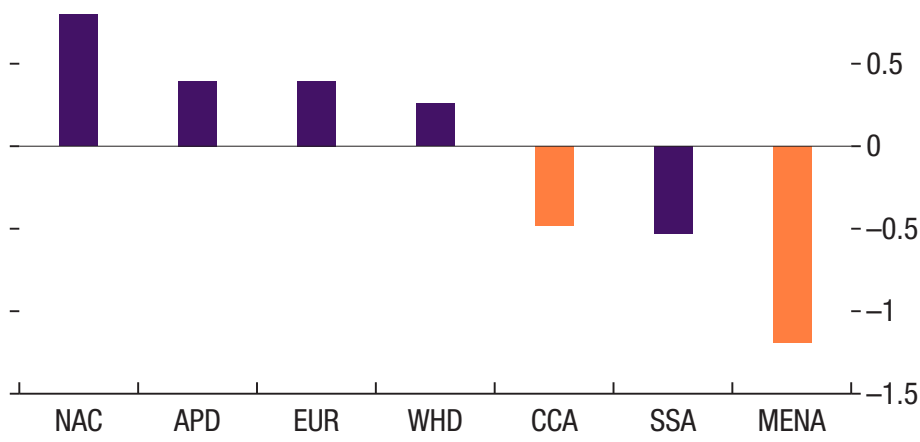

\section{Informality}

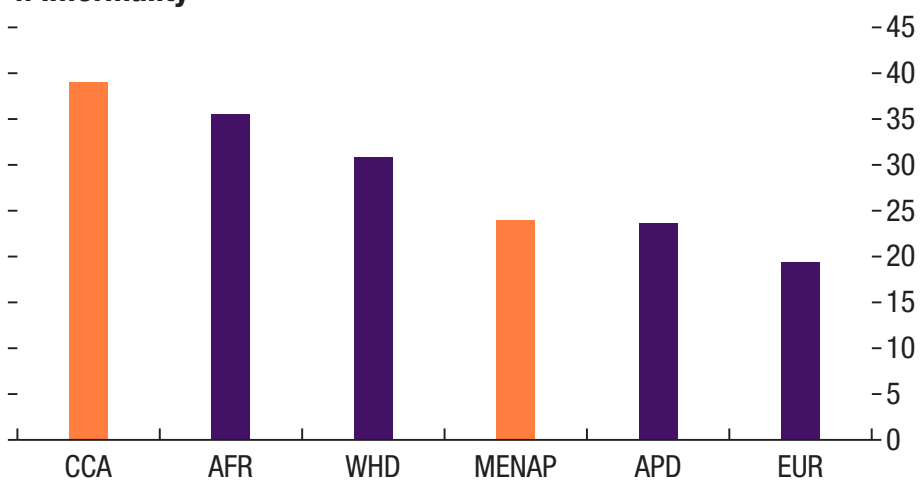

\section{Diversification}

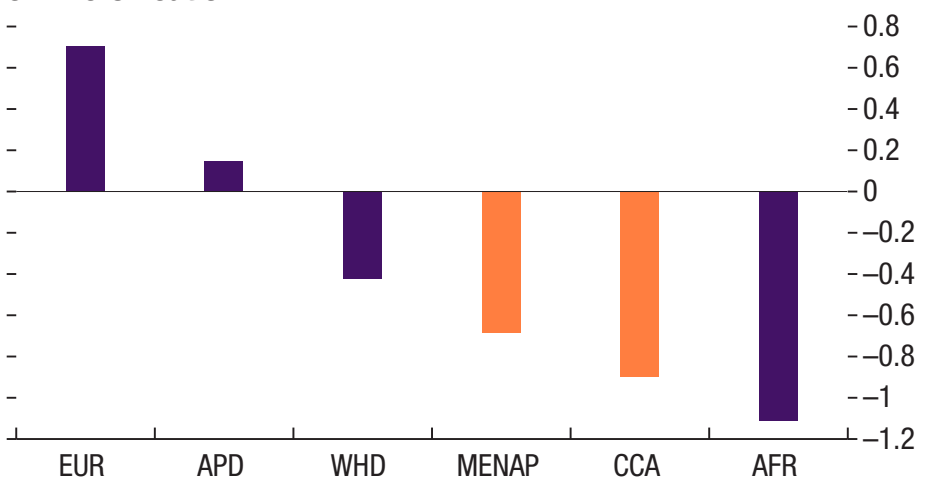

Sources: Worldwide Governance Indicators; Global Competitiveness Index, OECD—latest available data. 


\section{Annex Figure 7.2. The MacroFinancial Environment and SME Financial Inclusion}

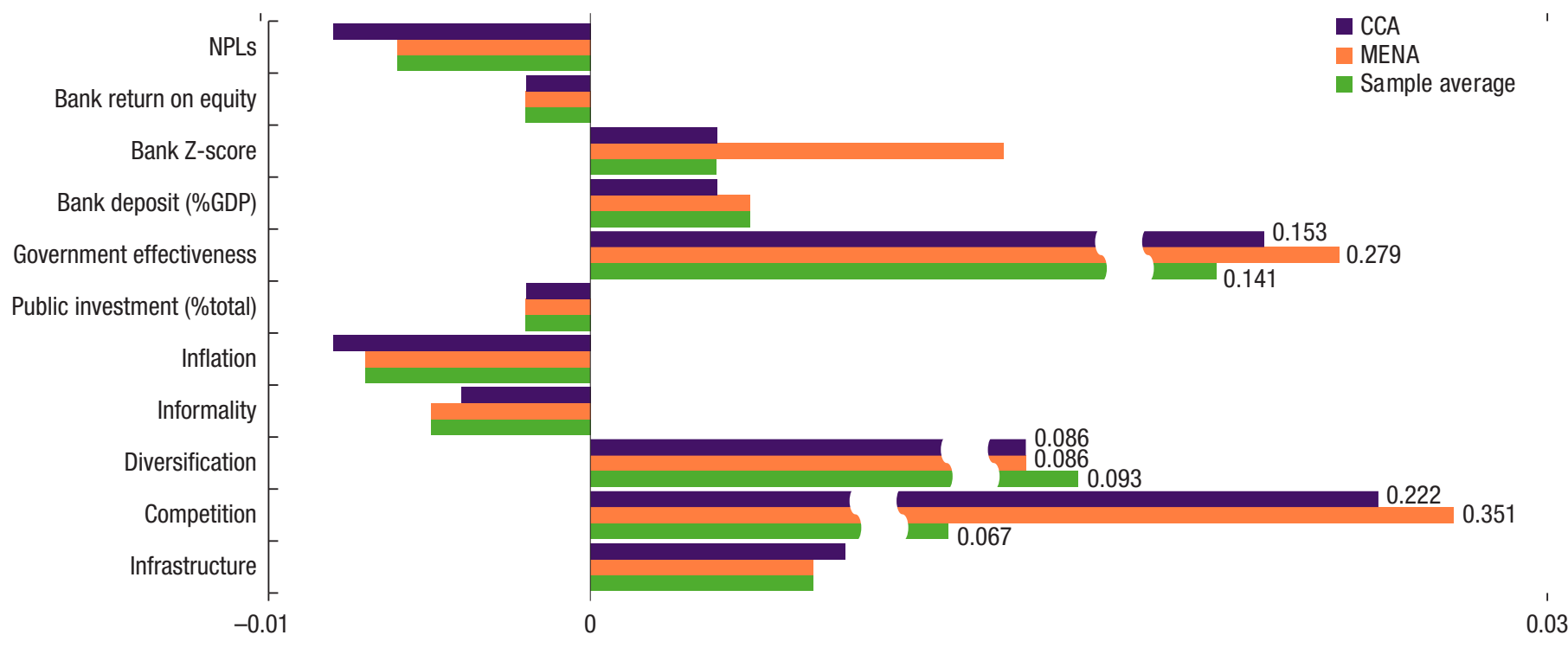

\section{Annex Figure 7.3. Institutions, Business Environment, and SME Financial Inclusion}

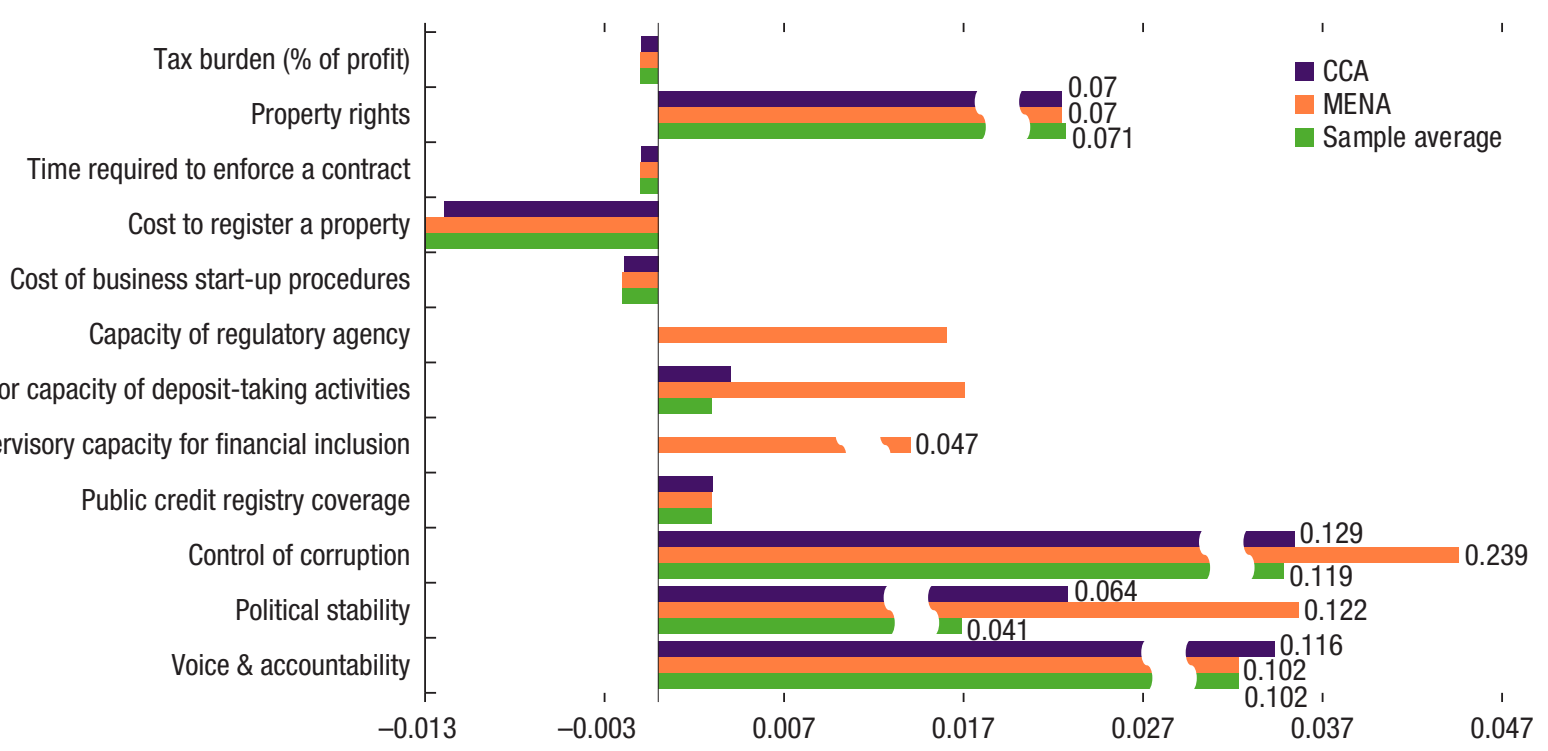

Source: IMF staff estimates.

Note: Coefficient estimates from equations (1) and (2), based on OLS panel fixed effects. The coefficients are statistically significant at a minimum level of $10 \%$, with robust standard errors. 


\section{References}

Abraham F., and S. Schmukler. 2017. "Addressing the SME Finance Problem.” Research and Policy Brief 9, World Bank Malaysia Hub, World Bank, Washington, DC.

Albuquerque, R., and H. A. Hopenhayn. 2004. "Optimal Lending Contracts and Firm Dynamics." Review of Economic Studies 71 (2): 285-315.

Allen, F., A. Demirguc-Kunt, L. Klapper, and M. Soledad. 2012. "The Foundations of Financial Inclusion: Understanding Ownership and Use of Formal Accounts." World Bank Policy Research Working Paper 6290, Washington, DC.

Anzoategui, D., M. Martinez Peria, and R. Rocha, 2010. "Bank Competition in the Middle East and Northern Africa Region." Review of Middle East Economics and Finance 6 (2).

Arcand, J., E. Berkes, and U. Panizza. 2015. “Too Much Finance?” Journal of Economic Growth 20:105-48.

Arellano, M., \& Bond, S. (1991). Some tests of specification for panel data: Monte Carlo evidence and an application to employment equations. The review of economic studies, 58 (2), 277-297.

Asian Development Bank (ADB). 2014. "Capital Market Financing for SMEs: A Growing Need in Emerging Asia.” ADB Working Paper Series on Regional Economic Integration, Manila.

Ayyagari, M., A. Demirguc-Kunt, and V. Maksimovic. 2014. "Who Creates Jobs in Developing Countries?" Small Business Economics 43 (1): 75-99.

Ayyagari, M., P. Juarros, M. Peria, and S. Singh. 2016. "Access to Finance and Job Growth: Firm-Level Evidence across Developing Countries." World Bank Policy Research Working Paper 7604, Washington, DC.

Baduel and others

Beck, T., A. Demirguc-Kunt, L. Laeven, and R. Levine. 2008. "Finance, Firm Size and Growth." Journal of Money Credit and Banking 40 (October).

Beck, T., A. Demirguc-Kunt, and V. Maksimovic. 2005. "Financial and Legal Constraints to Growth: Does Firm Size Matter?” Journal of Finance LX (1).

— 2008. "Financing Patterns around the World: Are Small Firms Different? Journal of Financial Economics 89:467-87.

Beck, T., A. Demirguc-Kunt, and D. Singer. 2013. "Is Small Beautiful? Financial Structure, Size and Access to Finance." World Development 52:19-33. 
Bank for International Settlements (BIS). 2018. "Sound Practices: Implications of Fintech Developments for Banks and Bank Supervisors." Basel.

Berton, F., S. Mocetti, A. Presbitero and M. Richiardi. 2018. "Banks, Firms, and Jobs." Review of Financial Studies 31:2113-56.

Bhattacharya, R., and H. Wolde. 2010. "Constraints on Growth in the MENA Region.” IMF Working Paper 10/30, International Monetary Fund, Washington, DC.

Blundell, R. et Bond, S. (1998). "Initial conditions and moment restrictions in dynamic panel data models", Journal of Econometrics 87, pp. 115-143

Bos, J. W. B., R. De Haas, and M. Millone. 2016. "Show Me Yours and I'll Show You Mine: Sharing Borrower Information in a Competitive Credit Market.” BAFFI CAREFIN Centre Research Paper 2015-8, Milan.

Brown, M., T. Jappelli, and M. Pagano. 2009. "Information Sharing and Credit: Firm-Level Evidence from Transition Countries." Journal of Financial Intermediation 18:151-72.

Calice, P. 2016. "Assessing Implementation of the Principles for Public Credit Guarantees for SMEs.” World Bank Group Finance and Markets Global Practice Group, Washington, DC.

Chatzouz. M., A. Gereben, F. Lang, and W. Toufs. 2017. "Credit Guarantee Schemes for SME Lending in Western Europe." EIF Research \& Market Analysis Working Paper 2017/42, European Investment Fund, Luxembourg.

Chodorow-Reich, G. 2014. "The Employment Effects of Credit Market Disruptions: Firm-Level Evidence from the 2008-9 Financial Crisis." Quarterly Journal of Economics 129 (1): 1-59.

Cihak, Martin; Mare, Davide Salvatore; Melecky, Martin. 2016. The Nexus of financial inclusion and financial stability : a study of trade-offs and synergies (English). Policy Research working paper; no. WPS 7722. Washington, D.C. : World Bank Group.

Clarke, G., R. Cull, M. Martinez Peria, and S. Sanchez. 2003. "Foreign Bank Entry: Experience, Implications for Developing Economies and Agenda for Further Research.” World Bank Research Observer 18 (1): 25-59.

Clementi, G. L., and H. A. Hopenhayn. 2006. "A Theory of Financing Constraints and Firm Dynamics." Quarterly Journal of Economics 121 (1): 229-65.

Dabla-Norris, E., Y. Deng, A. Ivanova, I. Karpowicz, F. Unsal, E. VanLeemput, and J. Wong. 2015a. "Financial Inclusion: Zooming in on Latin America." IMF Working Paper 15/206, International Monetary Fund, Washington, DC. 
Dabla-Norris, E. Y. Ji, R. Townsend, and F. Unsal. 2015b. "Identifying Constraints to Financial Inclusion and Their Impact on GDP and Inequality: A Structural Framework for Policy.” IMF Working Paper 15/22, International Monetary Fund, Washington, DC.

de la Torre, A., A. Ize, A, and S. Schmukler. 2011. "Financial Development in Latin America and the Caribbean: The Road Ahead." World Bank, Washington, DC.

Djankov, S., O. Hart, C. McLiesh, and A. Shleifer. 2008. "Debt Enforcement around the World." Journal of Political Economy 116 (6).

Djankov, S., C. McLiesh, and A. Shleifer. 2007. "Private Credit in 129 Countries." Journal of Financial Economics 84:299-329.

Duygan-Bump, B., A. Levkov, and J. Montoriol-Garriga. 2015. "Financing Constraints and Unemployment: Evidence from the Great Recession.” Journal of Monetary Economics 75:89-105.

European Bank for Reconstruction and Development (EBRD), European Investment Bank (EIB), and World Bank (WB). 2016. "What's Holding Back the Private Sector in Mena? Lessons from the Enterprise Survey." Washington, DC.

Faccio, M. 2006. "Politically Connected Firms." American Economic Review 96:369-86.

Farazi, S. 2014. "Informal Firms and Financial Inclusion: Status and Determinants." World Bank Policy Research Working Paper 6778, Washington, DC.

Ferrari, A., O. Masetti, and J. Ren. "Interest Rate Caps: The Theory and The Practice." World Bank Policy Research Working Paper 8398, Washington, DC.

Federation of European Securities Exchanges (FESE). 2012. "SME Access to Capital Markets Funding.” Brussels.

Financial Stability Board (FSB). 2017. "FinTech Credit: Market Structure, Business Models and Financial Stability Implications." Report prepared by a Committee on the Global Financial System and Financial Stability Board working group. Basel.

Gormley, T. 2010. "The Impact of Foreign Bank Entry in Emerging Markets: Evidence from India." Journal of Financial Intermediation 19:26-51.

Harwood, A., and T. Konidaris. 2015. "SME Exchanges in Emerging Market Economies: A Stocktaking of Development Practices.” Finance and Markets Global Practice Group, World Bank, Washington, DC. 
International Finance Corporation (IFC). 2011. "SME Finance Policy Guide.” Washington, DC.

International Monetary Fund (IMF). 2017a. "Ensuring Financial Stability in Countries with Islamic Banking." IMF policy paper, Washington, DC.

_. 2017b. "Fintech and Financial Services: Initial Considerations." IMF staff discussion note, Washington, DC.

- 2017c. "Recent Trends in Correspondent Banking Relationships: Further Considerations.” IMF policy paper, Washington, DC.

- 2017d. Regional Economic Outlook: Middle East and Central Asia. Washington, DC, October.

—. 2017e. "Supporting Growth and Inclusion through Financial Development.” IMF Country Report 17/213, Pakistan Selected Issues Paper, Washington, DC.

- 2018a. "Finance and Fintech: Invigorating Investment and Inclusion in India." Remarks by IMF Deputy Managing Director Tao Zhang, Mumbai, March 12.

—. 2018b. "Financial Inclusion in Asia Pacific." IMF Departmental Paper 18/17, Washington, DC.

. 2018c. Regional Economic Outlook: Middle East and Central Asia. Washington, DC, October.

. Forthcoming. "SME Financial Inclusion in the MCD Region." IMF Working Paper, Washington, DC.

International Organization of Securities Commissions (IOSCO). 2014. "Market-Based Long-Term Financing Solutions for SMEs and Infrastructure." Madrid.

—. "SME Financing through Capital Markets: Final Report.” Madrid.

Kumar, R. 2017. "Targeted SME Financing and Employment Effects: What Do We Know and What Can We Do Differently?" Jobs Working Paper (3) World Bank, Washington, DC.

Kuntchev, V., R. Ramalho, J. Rodriguez-Meza, and J. Yang. 2013. 'What Have We Learned from the Enterprise Surveys Regarding Access to Credit by SMEs?” Policy Research Working Paper 6670, Enterprise Analysis Unit, Financial and Private Sector Development, World Bank, Washington, DC.

Love, I., and M. Martinez Peria. 2015. "How Bank Competition Affects Firms' Access to Finance.” World Bank Economic Review 29 (3): 413-48.

Love, I., M. Martinez Peria, and S. Singh. 2016. "Collateral Registries for Movable Assets: Does Their Introduction Spur Firms' Access to Bank Financing?" Journal of Financial Services Research 49:1-37. 
Lukonga, I. 2018. "Fintech, Inclusive Growth and Cyber Risks: A Focus on the MENAP and CCA Regions.” IMF Working Paper, Washington, DC.

Lyman, T., and W. Noor. 2014. "AML/CFT and Financial Inclusion: New Opportunities Emerge from Recent FATF Action.” CGAP Focus Note 98, World Bank, Washington, DC.

Mehrotra, A., and J. Yetman. 2014. "Financial Inclusion and Optimal Monetary Policy.” BIS Working Paper 476, Bank for International Settlements, Basel.

Melecky, M., and A. Podpiera. 2018. "Financial Sector Strategies and Financial Sector Outcomes. Do the Strategies Perform?” World Bank Policy Research Paper 8315, Washington, DC.

Mills, K. G., and B. McCarthy. 2017. "The State of Small Business Lending: Innovation and Technology and the Implications for Regulation.” Harvard Business School, Cambridge, MA.

Organization for Economic Co-operation and Development (OECD). 2015. "Opportunities and Constraints of Market-Based Financing for SMEs."

OECD report to G20 finance ministers and central bank governors. Paris.

_. 2017. "Evaluating Publicly Supported Credit Guarantee Programs for SMEs.” Paris.

_ European Commission, and European Training Foundation. 2018.

"SME Index-The Mediterranean Middle East and North Africa 2018Interim Assessment of Key SME Reforms.” Paris.

Polish Agency for Enterprise Development (PARP). 2014. "Report on the Condition of Small and Medium-Sized Enterprise Sector in Poland in 2012-2013." Warsaw.

Popov, A., and J. Rocholl. 2016. "Do Credit Shocks Affect Labor Demand? Evidence for Employment and Wages during the Financial Crisis." Journal of Financial Intermediation 36 (October): 16-27.

Reuters. 2018. "Alibaba-Backed Online Lender MYbank Owes Cost-Savings to Home-Made Tech.” Reuters Business News. https://www.reuters.com/ article/us-china-banking-mybank/alibaba-backed-online-lender-mybank-owes -cost-savings-to-home-made-tech-idUSKBN1FL3S6.

Rocha, R., S. Farazi, R. Khouri, and D. Pearce. 2010. “The Status of Bank Lending to SMEs in the Middle East and North Africa Region: The Results of a Joint Survey of the Union of Arab Banks and the World Bank.” World Bank and Union of Arab Banks, Washington, DC. 
Rojas-Suárez, L. 2016. "Financial Inclusion in Latin America: Facts, Obstacles and Central Banks' Policy Issues.” Discussion Paper IDB-DP-464, Inter-American Development Bank, Washington, DC.

— cial Inclusion Gap.” Center for Global Development Working Paper 367, Washington, DC.

Sahay, R., M. Čihák, P. N’Diaye, A. Barajas, S. Mitra, A. Kyobe, Y. Mooi, and S. Yousefi. 2015. "Financial Inclusion: Can It Meet Multiple Macroeconomic Goals?” IMF Staff Discussion Note 15/17, International Monetary Fund, Washington, DC.

Toronto Centre. 2017. "FinTech, RegTech and SupTech: What They Mean for Financial Supervision." TC Notes (August).

UK Government. 2014. "SME Finance: Help to Match SMEs Rejected for Finance with Alternative Lenders." London.

World Bank. 2015. "Principles for Public Credit Guarantee Schemes for SMEs." Task Force for the Design, Implementation and Evaluation of Public Credit Guarantee Schemes for Small and Medium Enterprises, Washington, DC.

- 2016. "Competition in the GCC SME Lending Markets: An Initial Assessment." Middle East and North Africa Region GCC Country Unit report, Washington, DC.

World Bank. 2018a. "Bankers without Borders.” Global Financial Development Report, Washington, DC.

_. 2018b. "The World Bank Group’s Joint Capital Market Program.” Washington, DC.

—, International Monetary Fund (IMF), and Organization for Economic Co-operation and Development (OECD). 2015. "Capital Market Instruments to Mobilize Institutional Investors to Infrastructure and SME Financing in Emerging Market Economies: Report for the G20.” Washington, DC.

Zarutskie, R. 2006. "Evidence on the Effects of Bank Competition on Firm Borrowing and Investment." Journal of Financial Economics 81:503-37. 